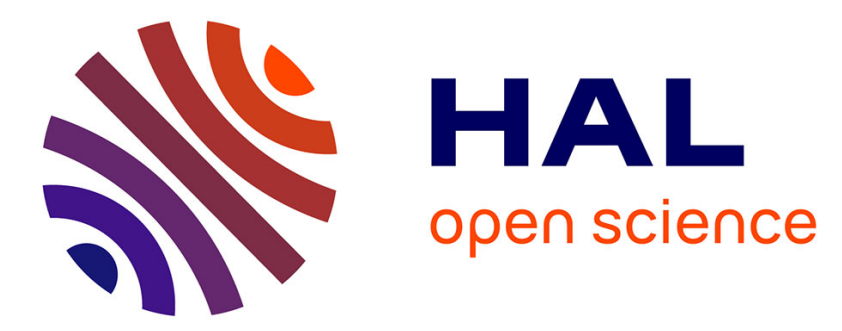

\title{
Small scale topography influence on the formation of three convective systems observed during COPS over the Vosges Mountains
}

Céline Planche, Wolfram Wobrock, Andrea Flossmann, Frédéric Tridon, Laurent Labbouz, Joël van Baelen

\section{To cite this version:}

Céline Planche, Wolfram Wobrock, Andrea Flossmann, Frédéric Tridon, Laurent Labbouz, et al.. Small scale topography influence on the formation of three convective systems observed during COPS over the Vosges Mountains. Meteorologische Zeitschrift, 2013, 22 (4), pp.395 - 411. 10.1127/09412948/2013/0402 . hal-01893478

\section{HAL Id: hal-01893478 \\ https://hal.uca.fr/hal-01893478}

Submitted on 11 Oct 2018

HAL is a multi-disciplinary open access archive for the deposit and dissemination of scientific research documents, whether they are published or not. The documents may come from teaching and research institutions in France or abroad, or from public or private research centers.
L'archive ouverte pluridisciplinaire HAL, est destinée au dépôt et à la diffusion de documents scientifiques de niveau recherche, publiés ou non, émanant des établissements d'enseignement et de recherche français ou étrangers, des laboratoires publics ou privés. 


\title{
Small scale topography influence on the formation of three convective systems observed during COPS over the Vosges Mountains
}

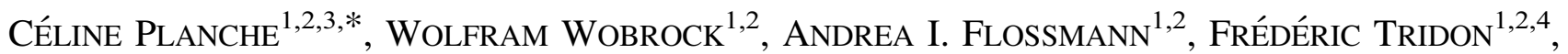 \\ LAURENT LABBOUZ ${ }^{1,2}$ and JOËL VAN BAELEN ${ }^{1,2}$ \\ ${ }^{1}$ Clermont Université, Université Blaise Pascal, Laboratoire de Météorologie Physique, Clermont-Ferrand, France \\ ${ }^{2}$ CNRS, INSU, UMR 6016, LaMP, Aubière, France \\ ${ }^{3}$ Present address: School of Earth and Environment, Institute for Climate and Atmospheric Science, \\ University of Leeds, Leeds, UK \\ ${ }^{4}$ Earth Observation Sciences, Department of Physics and Astronomy, University of Leicester, Leicester, UK
}

(Manuscript received June 13, 2012; in revised form November 27, 2012; accepted November 30, 2012)

\begin{abstract}
Numerical modelling of the airflow and precipitating convective systems are performed to better understand the role of topography for the triggering of convection over a moderate mountain region during the Convective and Orographically induced Precipitation Study (COPS) campaign. A non-hydrostatic cloud scale model with two nested domains is used which permits to zoom from the mesoscale environment of south-western Germany/eastern France, into the Vosges Mountains and finally into the small-terrain of the field experiment, increasing the grid resolution to well represent the orography of the region. Using radar observations, a classification of the location of the convection initiation was established during the COPS project, which considers that the convective systems form either on the mountain ridges or on the lee side of the massif. The three simulated cases of this study, corresponding to either position of convection initiation, compare well with available observations of local thermo-dynamical conditions, high resolution X-band radar reflectivity, Vienna Enhanced Resolution Analysis (VERA) of the surface horizontal wind and water vapour retrieval through GPS integrated water vapour 3D tomography. It was found that the convection generation is largely influenced by the Vosges topography. Even for a quite similar synoptic horizontal wind field, the relief acts differently for the studied cases. However, the convective systems are not formed solely by the mountains, but require inputs of moisture, proper stability, and some supportive mesoscale environment. Therefore, their representation in the model requires also a detailed knowledge of the local atmospheric conditions.
\end{abstract}

Keywords: cloud modelling, bulk microphysics, orography influence, COPS, weather radar, VERA, GPS tomography.

\section{Introduction}

Orography is an important source of perturbation and deformation of atmospheric flows (SMITH, 1979). Mountains can force the airflow to ascend and then can initiate the formation of clouds and rain through several generation mechanisms such as the upslope condensation and the triggering of convection. Consequently, the orography can have a significant impact on global and regional rainfall distribution (BANTA, 1990; BARROS and LETTENMAIER, 1994) and can also be able to induce severe events such as flash-flooding (PASTOR et al., 2010). The improvement of the quantitative precipitation forecasting over complex terrain is an important meteoro-

${ }^{*}$ Corresponding author: Celine Planche, School of Earth and Environment, Institute for Climate and Atmospheric Science, University of Leeds, Leeds, LS2 9JT, UK, e-mail: C.Planche@leeds.ac.uk logical objective that requires a better understanding of the mechanisms responsible for the formation of convective systems.

In this framework, several field campaigns have been performed in recent years addressing convection initiation and evolution in different landscapes such as the Convective Storms Initiation Project (CSIP) that took place over coastline areas in southern UK (BROWNING et al., 2007), the International H20 Project (IHOP) that took place over the Southern Great Plains in USA (WECKWERTH et al., 2004), and the Mesoscale Alpine Programme (MAP) that took place over the Alpine region (BOUGEAULT et al., 2001), among others. With a similar objective, the Convective and Orographically induced Precipitation Study Project (COPS) aims to understand the precipitating convection over a mountain region with moderate topography (WULFMEYER et al., 2008, 2011; KOTTMEIER et al., 2008). The COPS 
(a)
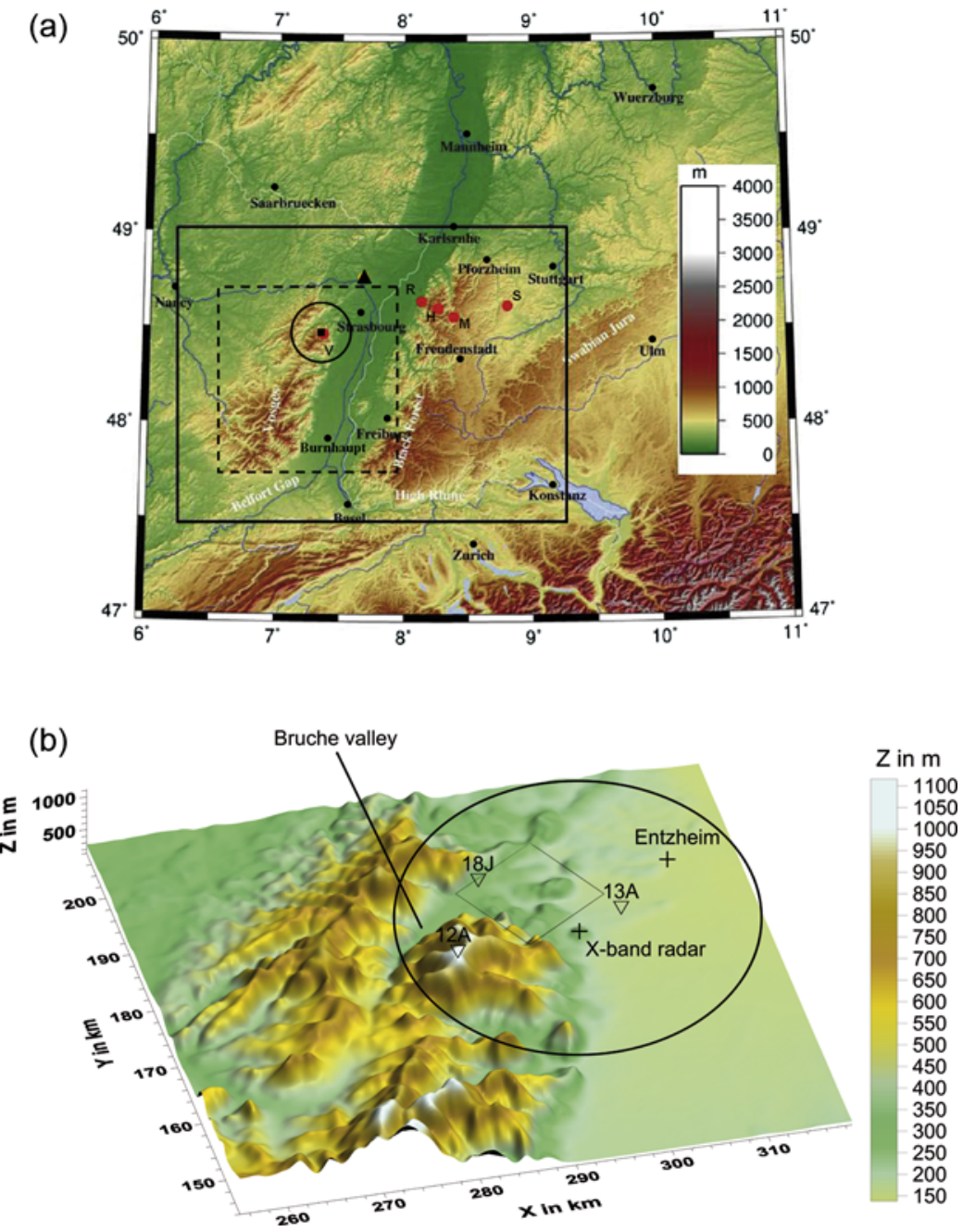

Figure 1: (a) Representation of the COPS domain (continuous lines). The red points indicate the 5 supersites of Stuttgart (S), Heselbach in the Murg Valley (M), Hornisgrinde (H), Achern (R) and Bischenberg/Meistratzheim in the Vosges Mountains (V). The black square and circle represent the position of the LaMP X-band radar and its range of measure. The black triangle shows the position of the POLDIRAD radar. The dashed lines delimit the second domain used in the simulations (Figure adapted from WULFMEYER et al., 2008). (b) Orographical map of the third innermost modelling domain used to simulate the $18^{\text {th }}$ of July and $13^{\text {th }}$ of August cases. The triangles indicate the location of the convective system onset for July 18 as well as August 12-13, 2007 and the black square indicates the topography modification used in the Section 4.

campaign took place during the summer 2007 at the French/German border from the Vosges Mountains to the Black Forest massif across the Rhine Valley (Fig. 1a) because this region is often characterized by a westerly flow with associated convective precipitation. A large number of in-situ and remote sensing instrumentation was deployed at 5 super sites located on both sides of the Rhine Valley (WULFMEYER et al., 2008). During the campaign period, many intensive observation periods (IOPs) were conducted providing a comprehensive data set covering different atmospheric conditions (WULFMEYER et al., 2011). For the studied cases, HAGEN et al. (2011) showed that the polarimetric C-band Doppler research radar (POLDIRAD, SCHROTH et al., 1988) allows a differentiation of precipitating cells according to their locations of initiation: on the crest or in the lee of the mountains.

Numerical modelling of air flow and precipitation fields can provide a complementary tool to the observations in order to better understand the dynamical and thermo-dynamical conditions which prevailed during the formation of different convective systems as well as the relief influence. However, as indicated by COSMA et al. (2002), a sufficiently high horizontal resolution is necessary to characterise the small scale topography and correctly reproduce the formation conditions.

The main objective of this modelling study is to analyse the conditions that prevailed prior to the convective system formation and to understand the effects of the topography at small scale on the convective system 
formation during certain episodes of the COPS campaign. Thus, the atmospheric patterns of three different cases will be analysed (July 18 and August 12-13, 2007) pertaining to both locations of the Hagen et al. classification (HAGEN et al., 2011). After a brief description of the model and its set-up in Section 2, the simulation results are compared with the available observations of the different cases. Section 3 allows validating the model results prior to the analysis of the impact of the terrain on the convective system formation. Thereafter, in Section 4, the local features of the atmosphere and the conditions in the adjacent area are studied to isolate the prevailing mechanisms in the formation of these convective systems as well as the influence of the northern Vosges relief. Finally, Section 5 summarizes and concludes the findings.

\section{Simulations description}

\subsection{Cloud scale model}

The dynamical framework employed in the present study is the three-dimensional, non-hydrostatic and anelastic cloud scale model developed by Clark and others coworkers (CLARK, 1977, CLARK and HALL, 1991; CLARK et al., 1996). This model is an established tool for the simulation of the airflow and the formation of clouds over complex terrain on small meteorological scales (ClARK et al., 2000; WOBROCK et al., 2003) and its application with a high horizontal and vertical resolution can provide important insights in the cloud evolution process (LEROY et al., 2009; PLANCHE et al., 2010). The Clark-Hall model uses a terrain following vertical coordinate. The environmental variables are written in perturbation form according to CLARK (1979). A detailed description of the model version used herein can be found in CLARK et al. (1996). Below, only a brief summary of the essential features is given.

\subsubsection{Physical parameterizations}

The boundary conditions of the model assume free-slip conditions for the momentum components and zero normal second derivatives of all scalar variables at the upper and lower surface of the model. In order to prevent reflection of the vertically propagating gravity waves at the model top $(20 \mathrm{~km})$, a Rayleigh friction and Newtonian cooling absorber is employed in the uppermost region of the model. The lateral boundary conditions are treated using a combination of specification and extrapolation. At outflow boundaries the normal velocity component is calculated using the extrapolation procedure of ORLANSKI (1976). All other field values are obtained by taking one-sided "averages" of the advection equations. At inflow boundaries, the normal velocity is treated by a combination of the Orlanski scheme and time relaxation to environmental values. The topography which characterised the model surface is given by the GTOPO30 data base (DANKO, 1992). It is a Global digital Elevation Model (GEM) with a horizontal grid spacing of 30 arc seconds (approximately $600 \mathrm{~m}$ in longitude and 900 $\mathrm{m}$ in latitude) and a vertical resolution of $1 \mathrm{~m}$ as provided by the US Geological Survey (USGS). When the simulations use finer resolution, as in this study, these data are filtered using a $2 \times 2$ points average. It is clear that all small hills and obstacles cannot be resolved but it is supposed that the topography used hereafter is sufficiently accurate to analyse its impact on the formation of convective systems.

Radiative cooling and heating rates in the clouds were not considered. Incoming radiative fluxes do only interact with the earth surface and thus determine the up-down welling fluxes of sensible and latent heat. Indeed, 10\% of the incoming radiative fluxes are assumed to be converting into surface fluxes. The variability of the fluxes depends then on the altitude, the direction of the relief slope and the sun's inclination angle (MAHRER and PIELKE, 1977). The distribution of the fluxes according to the relief properties follows the approach of KONDRATYEV (1969) where the solar radiation on a slant surface is given by:

$$
S_{s l}=S_{0} \cos i,
$$

where $i$ is the angle of incidence of solar rays on the inclined surface, and:

$$
\cos i=\cos \alpha \cos Z+\sin \alpha \sin Z \cos (\beta-\eta)
$$

with $\alpha$ is the slope angle, $Z$ is the zenith angle, $\beta$ and $\eta$ are solar and slope azimuths.

However, this approach does not consider the surface cover heterogeneity. The model's surface friction treatment is characterized by the logarithmic velocity profile law (STULL, 1988), where the roughness length is assumed to be equal to $2 \mathrm{~m}$ in a mountainous area (CLARK et al., 1996). The drag coefficient, which is based on the similarity theory, and the wind velocity provide then the surface shear stress. Furthermore, the Clark-Hall model uses several other physical parameterizations such as a turbulence scheme that is a first order Smagorinsky type (SMAGORINSKY, 1963).

\subsubsection{Microphysical parameterizations}

The microphysics in the Clark model uses bulk parameterizations for both the water and the ice phase. The water phase is parameterized according to the scheme of BERRY and REINHARDT (1974a,b). In this scheme, condensed water exists as cloud and rainwater. The ice phase parameterization closely follows the work of KOENIG and MURRAY (1976). This parameterization allows two types of particles, small ice crystals initially formed by heterogeneous ice nucleation or ice splinter processes and larger ice particles (aggregates, graupel) formed by collection 
process. Consequently, five categories (water vapour, cloud drops, raindrops, pristine ice and larger precipitating ice particles) of the water substance, characterised by the mixing ratio and the number concentration parameters, have to be taken into account in the equations for the conservation of heat, water, and ice substance. The two moment scheme for the ice parameterization is described in detail in BRUINTJES et al. (1994).

\subsection{Synoptic conditions of the study cases}

Three convective cases observed during the COPS campaign are analysed. The convective systems observed on July 18 and August 12-13 (Fig. 1b) represent the different cloud system formations of the Hagen et al. classification (HAGEN et al., 2011). Indeed, the cloud systems form over the Vosges' crests on the $12^{\text {th }}$ of August and on the leeside of the mountains on the $18^{\text {th }}$ of July and the $13^{\text {th }}$ of August. The synoptic conditions of these cases are different; however, a main westerly flow occurs in the COPS area for all of them.

On the July 18 (IOP-9a), a long-wave mid-/upper level trough initially stretched from the central part of Scandinavia over the North Sea and the British Isles south-westward towards the Azores. A rather intense ridge covered northern Africa, the western and central parts of the Mediterranean Sea region as well as south-eastern Europe. In between, a quite strong upper-level south-westerly flow was present from the Iberian Peninsula over the north-western parts of central Europe and the Baltic area. This southwesterly flow is visible in the radio sounding of Meistratzheim (Fig. 2a). Embedded in that flow, a surface frontal zone from south western France to northern Germany separated hot and moist air in the south of Eastern Europe from cooler and more stable air to the northwest, over British Isles. However, large scale forcing remained weak. In the COPS area, a few short-lived convective storms initiated at the north-eastern border of the Vosges Mountains around 17:00 UTC.

On the August 12 (IOP-15a), a weak front associated with a low-pressure system over Scotland approached the COPS area. The wind speed was low at the surface and oriented south-westerly. Above $700 \mathrm{hPa}$ the wind speed increased and turned more southerly (see sounding of Nancy, Fig. 2b). At the surface the air was hot with cold air above and downwind of the front some thunderstorms appeared in Western Europe due to convection. In the COPS area a single storm formed at 13:00 UTC on the crests of the northern Vosges Mountains.

The day after, i.e. on the August 13 (IOP-15b), an upper level trough originating south of Greenland progressed eastward and merged with the deep large scale upper low that was centred over the Scotland since the day before. Behind a partly convective rain system that passed over the area in the previous night, an upper-level shortwave trough passed the COPS area around noon. A few showers formed in the relatively clear air ahead of and near the trough. The most significant storms formed just east of the northern part of the Vosges mountain at 13:00 UTC and moved rapidly eastward across the Rhine Valley to the Black Forest.

\subsection{Model set-up}

For the three simulations presented here, the nested approach is similar. The domains are set to $384 \mathrm{x}$ $256 \mathrm{~km}^{2}$ in the horizontal and $16 \mathrm{~km}$ in the vertical. In the larger domain, the resolution is $4 \mathrm{~km}$ for the horizontal coordinates and $400 \mathrm{~m}$ for the vertical one. A second domain with a surface $130 \times 130 \mathrm{~km}^{2}$ and grid resolution of $1 \mathrm{~km}$ is nested over the Vosges Mountains. A third domain with a surface $64 \times 64 \mathrm{~km}^{2}$ and grid resolution of $250 \mathrm{~m}$ is nested inside the second one zooming into the area of interest, according to the case studied. The dynamical time step for every simulation is 3 seconds. The vertical resolution of both finer grids is $200 \mathrm{~m}$. This resolution is certainly too coarse near the surface in order to represent the detailed surface-atmosphere exchanges but permits a good representation of the cloud levels. On average for the three cases the simulations last $3 \mathrm{~h}$ and 30-45 min for the spin-up. In order to improve the sensible and latent heat fluxes at the surface, the lower model boundary was forced by the observations of EIGENMANN et al. (2009) done during the COPS experiment where the observed maximum values of sensible and latent surface heat fluxes at noon time and in the Rhine valley are equal to $70 \mathrm{~W} \mathrm{~m}^{-2}$ and $250 \mathrm{~W} \mathrm{~m}^{-2}$, respectively. The model considers these values at this time and location and then the temporal and spatial variations depend, as described in section 2.1.1, on the altitude, the direction of the relief slope and the sun's inclination angle.

In order to impose the large-scale influence on the local scale, the large-scale thermodynamics and dynamics reanalysed data (ERA-Interim reanalysis method explained in SIMMONS et al., 2007; DEE et al., 2011) of the 12:00 UTC ECMWF model are used as initial and boundary conditions for the largest grid (without data assimilation) and, the finer models are nested (two way) into the coarser one. As the ECMWF analyses are given by a $0.5^{\circ}$ (approx. $50 \mathrm{~km}$ ) grid resolution in geographical latitude and longitude they are interpolated between each point. However, these data alone do not trigger convection for all cases, mainly due to a lack of humidity in the lowest levels of the atmosphere (Fig. 2). Fig. 2 shows a comparison between the global profile $\left(48.5^{\circ} \mathrm{N}, 7.5^{\circ} \mathrm{E}\right)$ of the ECMWF reanalysis and the local profile measured during the COPS campaign the closest in time and space to the convection formation. For July 18, the local profile results from the sounding measured at Meistratzheim at 17:00 UTC. Its location is indicated by the V in Fig. 1a. As the soundings in Meistratzheim were only available during the month of July, the soundings of Nancy at 12:00 UTC are used for the August cases 
(a)

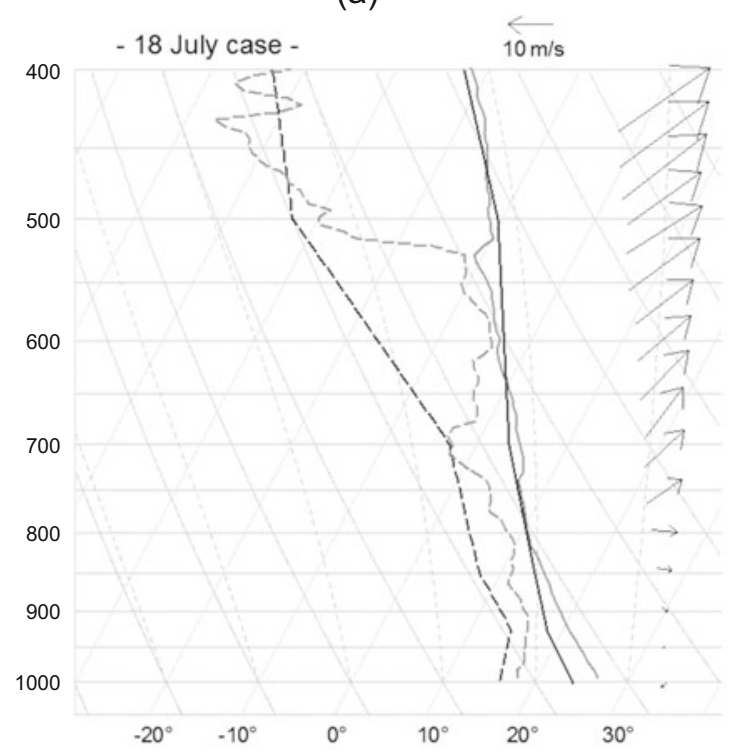

(b)

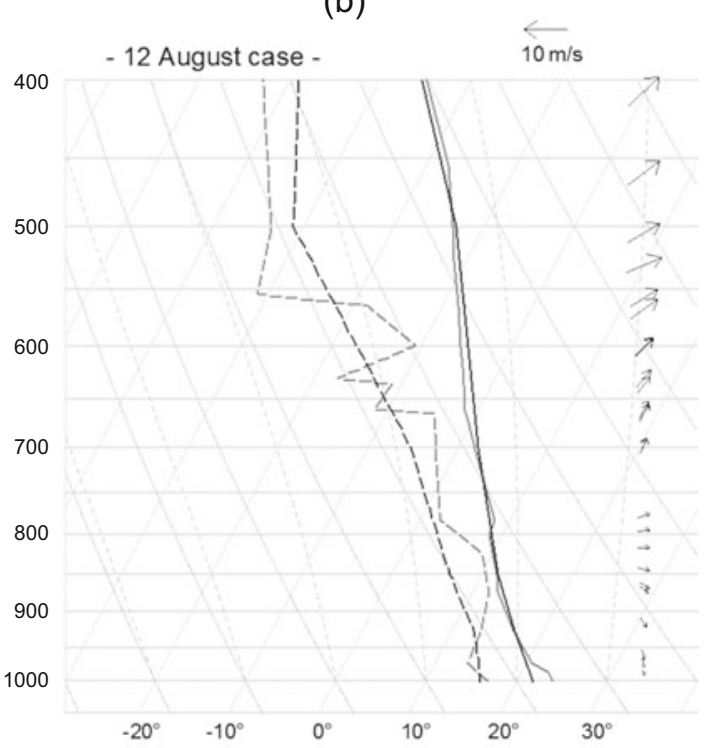

(c)

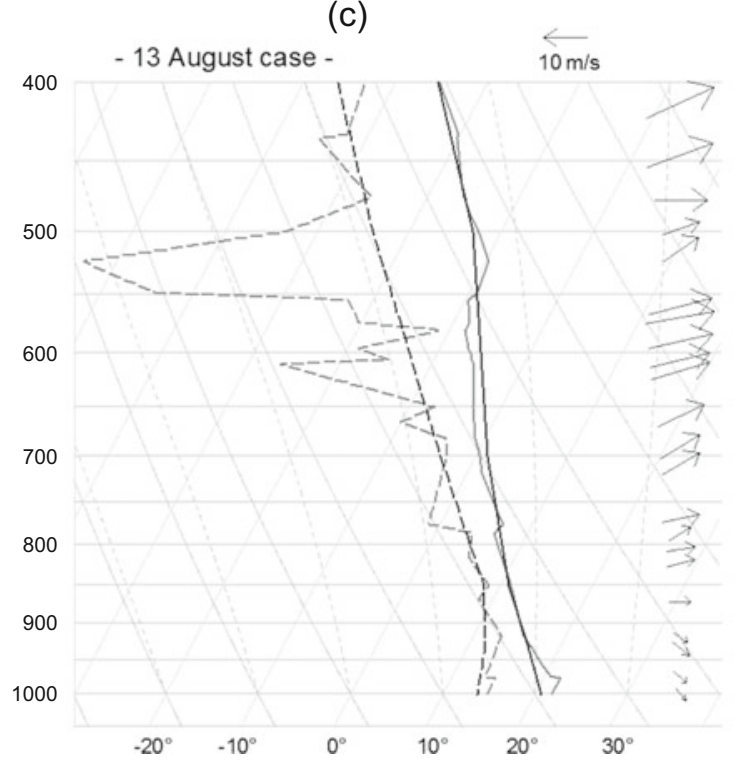

Figure 2: Temperature (solid line) and dew point temperature (dashed line) profiles from the ECMWF re-analysis (black) and from the sounding observed (red): (a) at Meistratzheim, July 18, 17:00 UTC; (b) at Nancy, August 12, 12:00 UTC; and (c) at Nancy, August 13, 2007, 12:00 UTC. The arrows represent the observed wind speed and horizontal direction.

$\left(12^{\text {th }}\right.$ and $\left.13^{\text {th }}\right)$. These soundings were the closest available profiles that characterised the air mass over the COPS area. Compared to the local Meistratzheim's sounding, the global profile of the $18^{\text {th }}$ of July is characterised by a lack of humidity up to $700 \mathrm{hPa}$ and the temperature is underestimated by approximately $2{ }^{\circ} \mathrm{C}$ below $800 \mathrm{hPa}$. The deficiency of humidity of the $12^{\text {th }}$ of August global profile is located between $950-800 \mathrm{hPa}$. Small differences in the temperature $\left(1.5^{\circ} \mathrm{C}\right)$ and humidity $\left(0.8 \mathrm{~g} \mathrm{~kg}^{-1}\right)$ fields near the surface can be observed between the global and local sounding for the $13^{\text {th }}$ of August.
Moreover, the $18^{\text {th }}$ of July local profile trend (Fig. 2a) follows the dry adiabatic conditions in the first $1.5 \mathrm{~km}$ whereas the $12^{\text {th }}$ of August profile (Fig. 2b) follows the wet adiabate. Nevertheless, these two profiles reveal an atmospheric instability in the lowest levels that could be favourable to vertical developments under forced conditions. In contrast, the $13^{\text {th }}$ of August profile (Fig. 2c) reveals a small stable layer up to $925 \mathrm{hPa}$ and an atmospheric instability above. The wind directions have an important westerly influence in the high levels. Some variations are visible in the lower levels where the directions are more north-westerly. For the $18^{\text {th }}$ of July case 
the wind velocities in the high atmospheric levels are stronger than in the two other cases whereas they are lower (approx. $2 \mathrm{~m} \mathrm{~s}^{-1}$ ) in the lowest levels of the atmosphere. The most important wind speeds near the surface are measured on the $13^{\text {th }}$ of August with a peak of $7 \mathrm{~m} \mathrm{~s}^{-1}$ whereas for the $12^{\text {th }}$ of August they are around $4 \mathrm{~m} \mathrm{~s}^{-1}$. Furthermore, the Convective Available Potential Energy (CAPE) is equal to 800,140 and $102 \mathrm{~J} \mathrm{~kg}^{-1}$ and the Convection Inhibition (CIN) is equal to $-16,-1$ and $-2 \mathrm{~J} \mathrm{~kg}^{-1}$ for the July 18 and August 12-13 case, respectively (LABBOUZ et al., 2013 and HAGEN et al., 2011). For the August simulations, the CAPE is quite low, but within the typical range for Central Europe.

As indicated in Fig. 1b, the locations of the three precipitating systems are close to the V supersite where the LaMP X-band radar was deployed during the campaign. In order to consider the local humidity and temperature trends, the global ECMWF thermodynamics profile near this position $\left(7.5^{\circ} \mathrm{E}-48.5^{\circ} \mathrm{N}\right.$ point $)$ which coincides with the Strasbourg-Entzheim airport location was replaced by local profile measurements and the available surface data, as discussed above. The altitudes of this local sounding used in the model are the same than those of the ECMWF reanalysis data and the handled values consider the observations over the layer located between two consecutive points. Then, the new sounding is interpolated with the surrounding ECMWF profiles (available every $0.5^{\circ}$ in geographical latitude and longitude) alike the default ECMWF analyses to not obtain unrealistic thermodynamics gradient.

\section{Validation of the model results}

According to the HAGEN et al. (2011) classification, the precipitating system of the $12^{\text {th }}$ of August formed over the crest of the Vosges whereas the $18^{\text {th }}$ of July and $13^{\text {th }}$ of August cases are initiated in the lee of the mountains. Before a detailed investigation of the impact of the terrain on the convective system formation, the different simulation results are compared to the available observations below. For a $3 \mathrm{D}$ evaluation, the observations used are the wind surface of the Vienna Enhanced Resolution Analysis (VERA, BAUER et al. (2011)), the water vapour GPS tomography (VAN BAELEN et al., 2011) and the radar reflectivity at high resolution with the LaMP Xband radar (PETERS et al., 2006; VAN BAELEN et al., 2009). During these comparisons, the respective problems and uncertainties of the observations have to be kept in mind, e.g. calibration and attenuation, perturbations of the signal, instrumental effects or locations of the stations (UIJLENHOET et al., 2006; HÄBERLI et al., 2004; VAN BAELEN et al., 2011).

\subsection{High resolution radar: analysis of the precipitating fields}

The LaMP X-band radar was deployed for 3 months at the Vosges French supersite near Meistratzheim (see
Fig. 1), $20 \mathrm{~km}$ to the south-west of Strasbourg. This radar is designed to provide the precipitation field over a small catchment basin (about $20 \mathrm{~km}$ range) with its high spatial and temporal resolution $\left(60 \mathrm{~m}\right.$ in range, $2^{\circ}$ in azimuth and $30 \mathrm{~s}$ in time) (VAN BAELEN et al., 2009). For this campaign, a fixed beam elevation of $5^{\circ}$ was used. This means that the height of the radar beam at $20 \mathrm{~km}$ distance is approximately $2 \mathrm{~km}$.

In this section, the modelled normalized radar reflectivity, $\mathrm{Z}_{\mathrm{dBZ}}$ (in $\mathrm{dBZ}$ ) are compared with the available radar observations according to the same method used by PLANCHE et al. (2010). The reflectivity is computed on the PPI (Plan Position Indicator) of the radar in order to perform direct comparison with its measurement all over the observational range. The simulated radar reflectivity is calculated with Z-R relationship $Z\left\lfloor\mathrm{~mm}^{6} \mathrm{~m}^{-3}\right\rfloor=$ $a R^{b}$ for the precipitating hydrometeors (STRAKA et al., 2000). As the analysis is focussed on the formation of the precipitating system, the different comparisons between model results and X-band radar observations are chosen close to the convective system initiation.

\subsubsection{IOP 9a: July 18, 2007}

On the afternoon of July 18 , a convective system forms in the lee of the Vosges Mountains, $15 \mathrm{~km}$ north-west of the Entzheim airport (see Fig. 1b), near the exit of the Bruche valley. The X-band radar observes this precipitating system between 16:54 and 18:00 UTC. Due to the strong horizontal wind component (Fig. 2a) provoked by the two low-pressure systems around the COPS area, the track of the system is north-eastward. According to observational studies of this IOP case (VAN BAELEN et al. (2011); LABBOUZ et al. (2013)), the precipitating system crosses the Rhine valley and dissipates near Karlsruhe in Germany. Figs. 3a and b show respectively the modelling results $10 \mathrm{~min}$ after the precipitation starts and the observed reflectivity field shortly after the precipitating cell formation. The modelled cloud system forms $15 \mathrm{~km}$ north of the X-band radar position and moves to the north-east towards the north of Strasbourg. The maximum intensity of the cell is well reproduced by the model with a slight offset of about $5 \mathrm{~km}$ to the north-east compared to the observation. Furthermore, the intensities of the radar reflectivity themselves are quite similar to the observed ones. For example, the maxima are approximately $45 \mathrm{dBZ}$ in the observations (Fig. 3b) as well as in the simulations (Fig. 3a). However, three weaker cells are modelled at the east of this intensive cell while they are not visible in the radar observations. Nevertheless, the modelled radar reflectivity fields of the main cell are comparable to the observed ones.

\subsubsection{IOP 15a: August 12, 2007}

In this case, the precipitating system forms over the Vosges crests, in the south-west of the radar's observational 
(a) - 18 July $2007-17 \mathrm{~h} 10-$

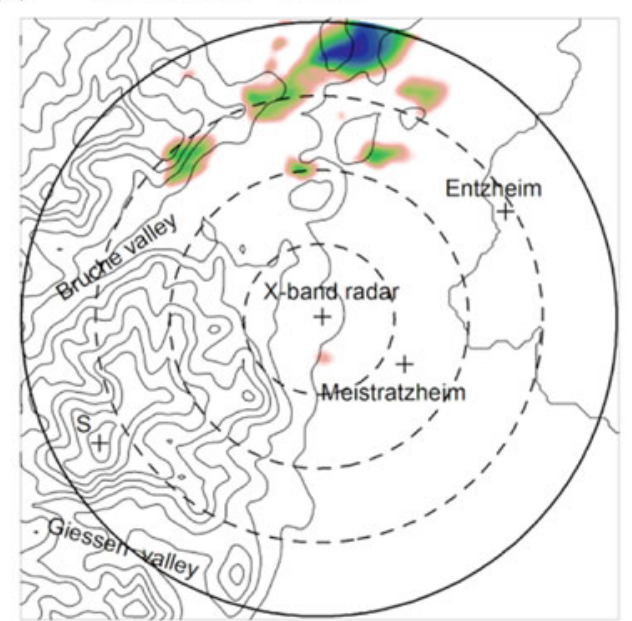

(c) - 12 August $2007-13 \mathrm{~h} 04-$

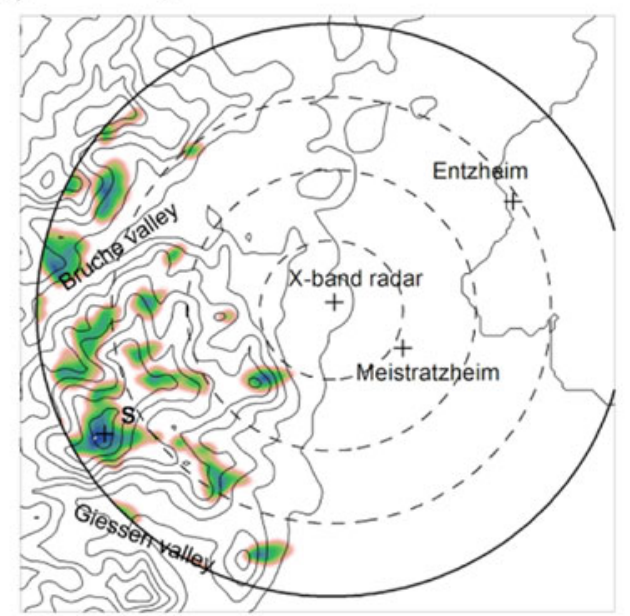

(e) - 13 August $2007-12 \mathrm{~h} 55$ -

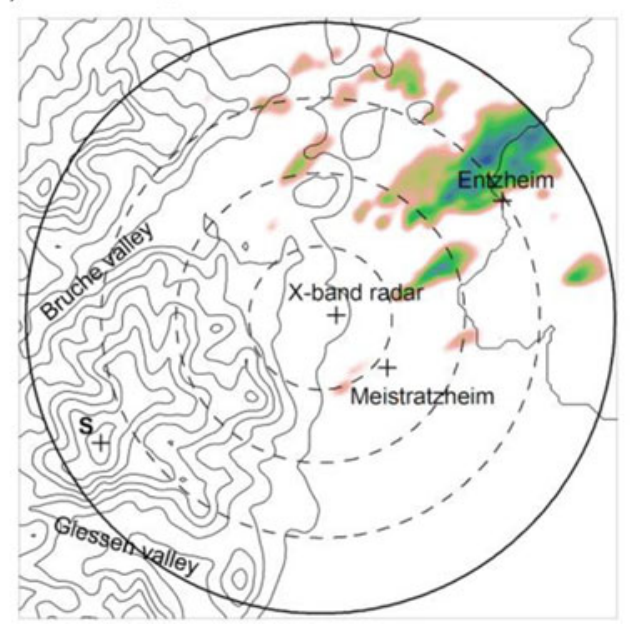

(b)

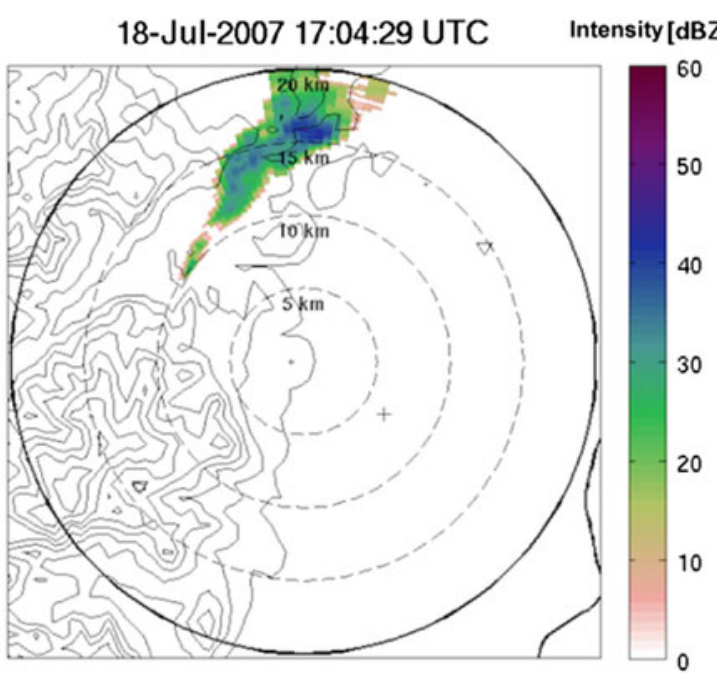

(d)

12-Aug-2007 13:07:30 UTC

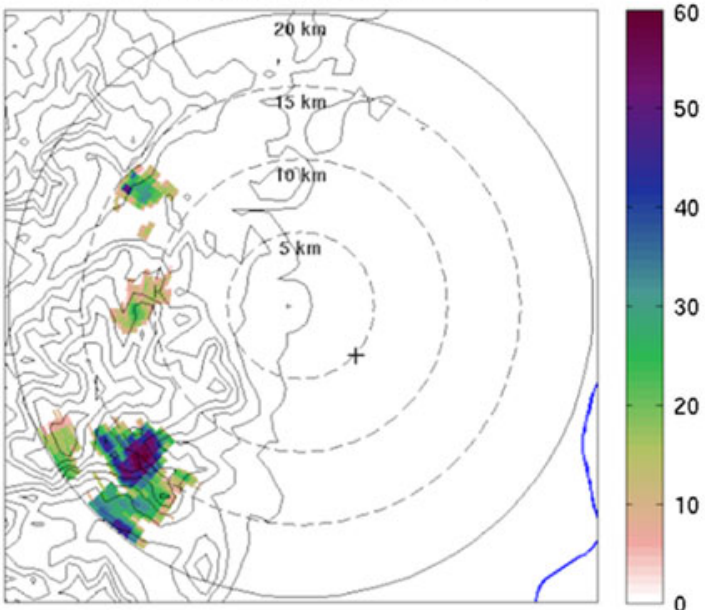

(f)

13-Aug-2007 12:54:30 UTC

Intensity [dBZ]

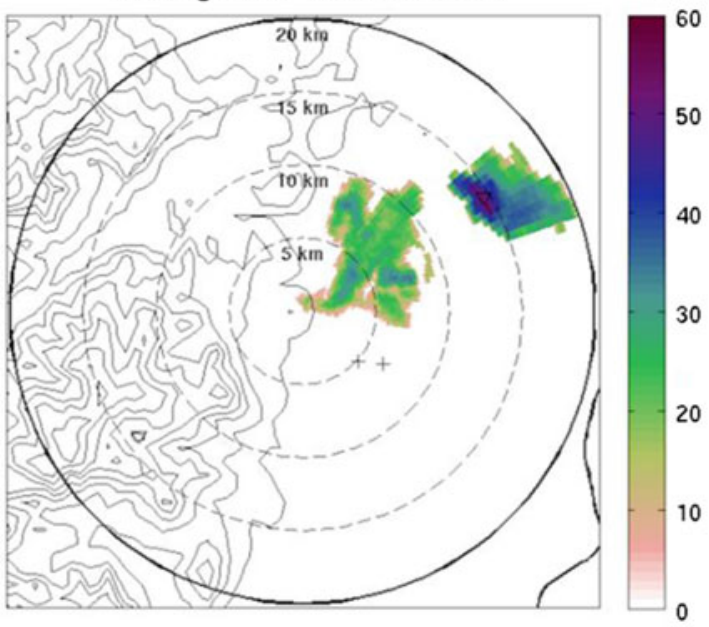

Figure 3: Comparison between the radar reflectivity modelled (left panels) and observed with the high resolution X-band radar (right panels) for July 18 (a-b), August 12 (c-d) and 13 (e-f). PPI observations used for $18^{\text {th }}$ of July, $12^{\text {th }}$ and $13^{\text {th }}$ of August cases are taken at 17:04, 13:07 and 12:54 UTC, respectively. The corresponding modelling results were taken 10, 5 and 10 min after rain onset, resp. The point S represents the summit named "Champ du Feu" (1099 m) of the northern Vosges Mountains. 
area at 12:59 UTC and moves to the radar position while the reflectivity intensity decreases. The convective system disappears above the radar position at 14:30 UTC (i.e. 90 min after its formation) whereas, in the simulations, it dissipates $5 \mathrm{~km}$ to the north of the radar position after $100 \mathrm{~min}$ of precipitation. Fig. 3d shows the reflectivity field observed at 13:07 UTC (8 min after rain onset) whereas Fig. $3 c$ represents the modelled reflectivity field obtained after $5 \mathrm{~min}$ of precipitation. These panels show that several convective cells formed over the observational area of the X-band radar. The horizontal extension of these cells is different. The most intense one which formed over the peak of the Vosges is larger than the others which are located around this summit. These panels also show a shift of about $5 \mathrm{~km}$ between modelled and observed reflectivity maxima. Moreover the simulated convective cells are slightly more numerous than in the observations. Apart from that, the simulated reflectivity field structure compares well with the radar observations.

\subsubsection{IOP 15b: August 13, 2007}

The studied precipitating convective system of August 13 forms in the Rhine valley above Entzheim airport at nearly 12:40 UTC. This system persists there during approximately 20 minutes while, after 12:50 UTC, a second weaker convective cell forms near the X-band radar position. Fig. 3f shows the radar observations at 12:54 UTC, i.e. 4 min after the formation of the weaker precipitation cell. According to the observations, the maximum reflectivity intensity of the first cell is approximately $52 \mathrm{dBZ}$ whereas the second one reaches a lower maximum of $33 \mathrm{dBZ}$. The modelled precipitation field (Fig. 3e) corresponds to $5 \mathrm{~min}$ after the second cell's rain onset. The intensity of the first cell is slightly underestimated and the generation point of the second cell is shifted $6 \mathrm{~km}$ to the east of the radar position. Furthermore, the horizontal extensions are different. The modelled north-eastern cell is slightly more extended than the observed one and the second modelled cell is significantly smaller. Then, both simulated and modelled cells merge and move across the Rhine valley leaving the $\mathrm{X}$ band radar's detection range $90 \mathrm{~min}$ after the formation of the first precipitations. Finally, even though the position and extent of the cells are slightly different, the model results compare reasonably well with the high resolution X-band radar observations.

\subsection{VERA analysis tool: surface wind fields}

The Vienna Enhanced Resolution Analysis (VERA, STEINACKER et al. (2000)) is an analysis tool for applications over complex topography using physical knowledge of typical meteorological patterns in such areas. The system performs a spatial interpolation of irregularly distributed measurements to a regular grid and is based on variational principle using higher-order derivatives in two dimensions. Details of the analysis method can be found in STEINACKER et al. (2006). A comprehensive data quality-control scheme is applied upstream of the analysis to exclude erroneous data. This module detects and filters unrealistic single measurements, gross errors as well as systematic errors, and eliminates erroneous patterns caused by data errors in the spin-up of the analysis (HÄBERLI et al., 2004). The European Joint D-PHASE/ COPS dataset (DORNINGER et al., 2008; BAUER et al., 2011) was applied to produce the analyses on an hourly basis with a grid spacing of $8 \mathrm{~km}$ for the COPS period. Approximately, 75 and 10 stations were respectively located in the $1 \mathrm{~km}$ and $250 \mathrm{~m}$ model domain area used in this study. Most of these stations provided the wind field at $10 \mathrm{~m}$ height above the ground level. Nevertheless, some of them which are located at the top of masts or on the roof of buildings provided higher wind measurements.

\subsubsection{IOP 9a: July 18, 2007}

While a westerly surface wind arrives on the west slopes of the Vosges Mountains, a wind divergence appears (not shown) after crossing the Vosges massif at the same latitude as Freiburg (see Fig. 1a for location). At this point, the wind flows seem to be channelled in the Rhine valley in the south towards Burnhaupt and in the north towards Strasbourg. Fig. 4a and b focus on this southerly flow. Fig. 4a shows the modelled surface wind components ${ }^{1}$ at the time of the precipitation formation in the finest resolution domain close to the formation point (Fig. 1b). Fig. 4b represents the VERA analyses of the surface horizontal wind field over the same area at 15:00 UTC $(2 \mathrm{~h}$ before the rain onset). This panel reveals a westerly flow over the Vosges, a small divergence line in the Rhine valley (dashed line) and a convergence at the exit of the Bruche valley. Fig. 4a shows that the modelled features of the horizontal wind field at the surface are comparable to the observations. Indeed, the wind convergence near the exit of the Bruche valley (same latitude than Strasbourg) provokes a decrease of the wind intensity (from $2-3 \mathrm{~m} \mathrm{~s}^{-1}$ to about $0.5 \mathrm{~m} \mathrm{~s}^{-1}$ ) at the north of the Vosges massif. The observed wind intensity seems to be somewhat higher than in the simulations near the convergence area. This difference in the wind intensity can be due to the wind surface representation which is given at $125 \mathrm{~m}$ and $15 \mathrm{~m}$ height agl in, respectively, the simulations and VERA analysis. Moreover, there is a slight shift of the simulated convergence point of about $7 \mathrm{~km}$ to the north-east in the simulations and a temporal shift of about $2 \mathrm{~h}$ between the simulations and the observations.

\footnotetext{
${ }^{1}$ The modelled horizontal wind field at the surface corresponds to the wind field at $125 \mathrm{~m}$ height above the ground level. Hereafter, the "surface wind" expression will be used.
} 
(a) - 18 July $2007-17 \mathrm{~h} 00$

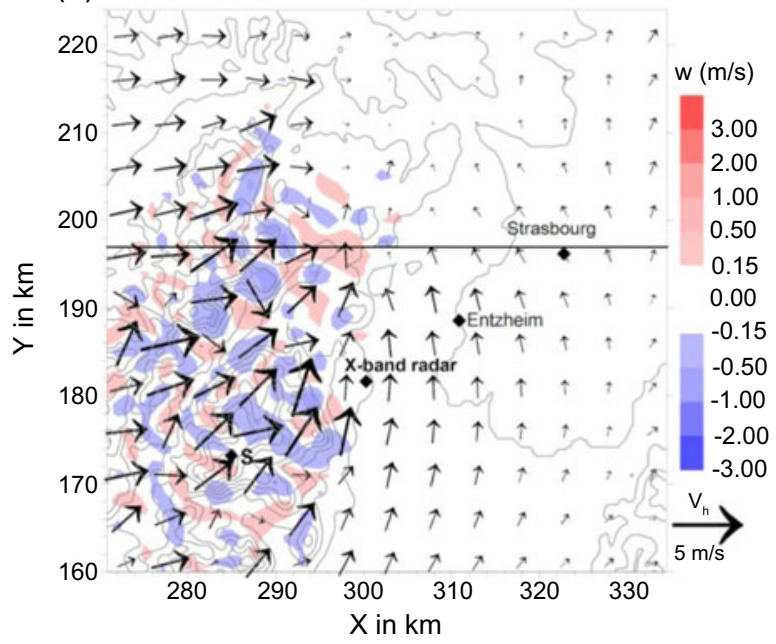

(c) - 12 August $2007-13 \mathrm{~h} 00$ -

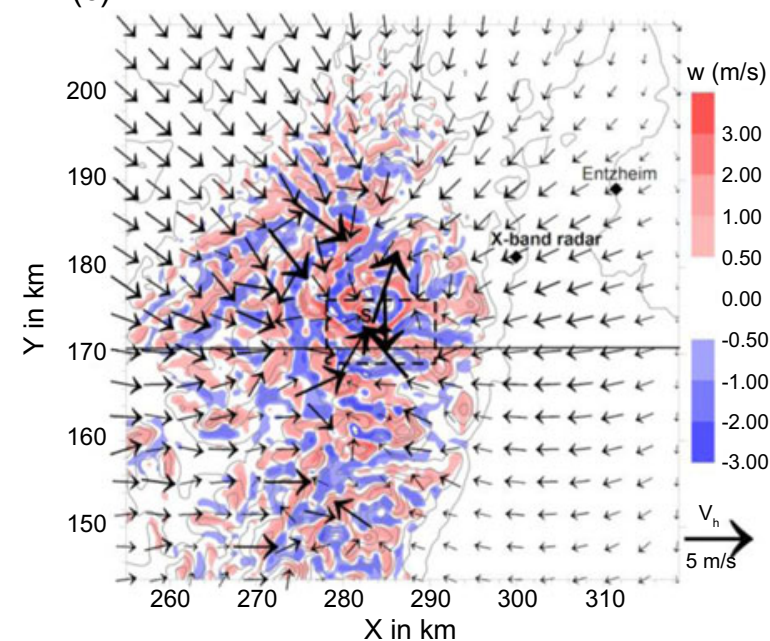

(e) -13 August $2007-12 \mathrm{~h} 40-$

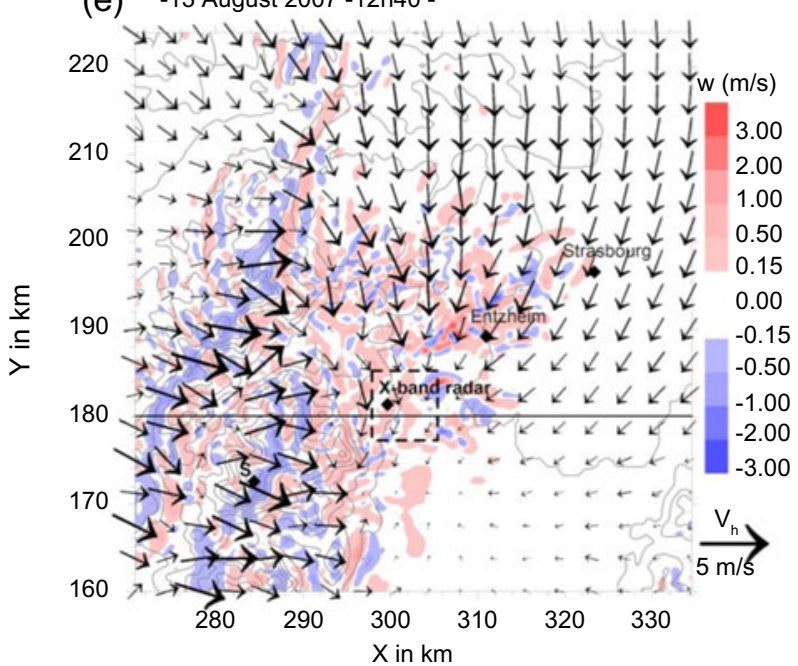

(b) 0718 VERA wind speed 15 UTC

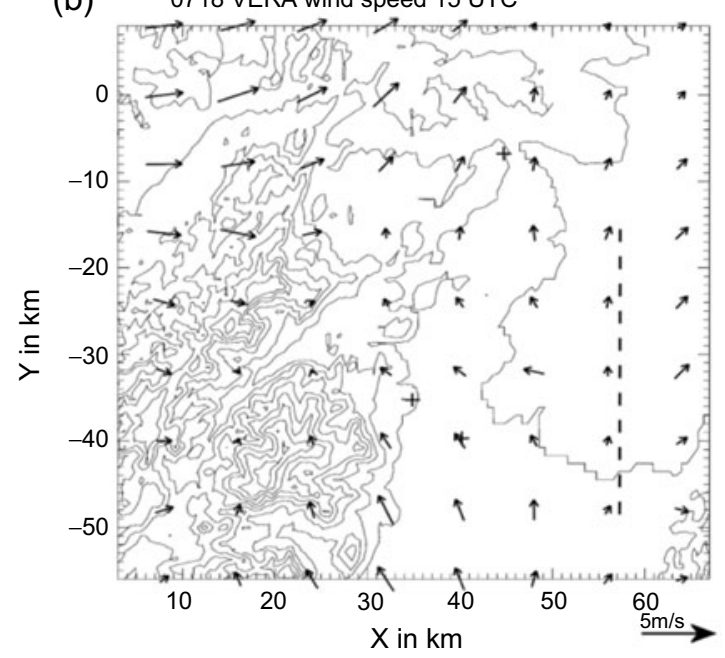

(d) 0812 VERA wind speed 14 UTC
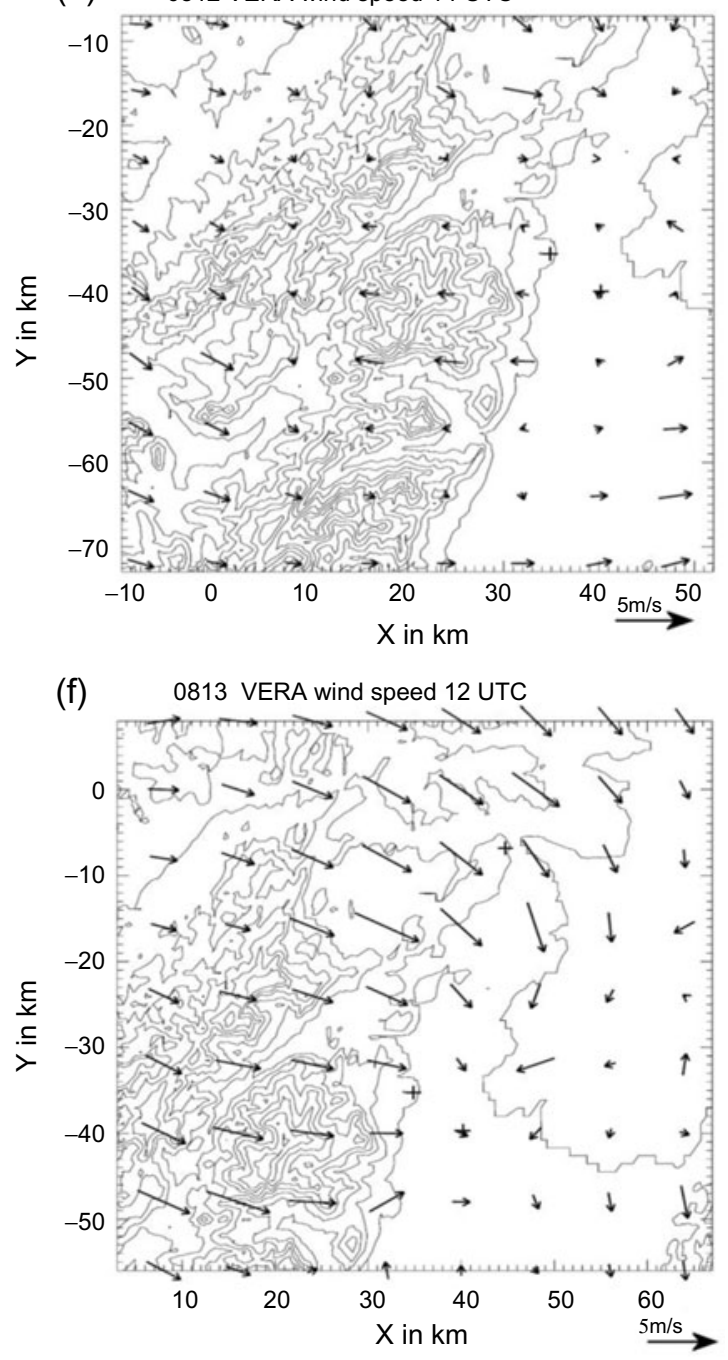

Figure 4: Comparison between the modelled horizontal wind close to the surface (125 m above the ground) over the higher resolution domain (left panels) and obtained at the surface (15 $\mathrm{m}$ in average) with the VERA analysis tool (right panels) for July 18 (a-b), August 12 (c-d) and 13 (e-f). The modelled figures are chosen at the time of the precipitating system formation. The observation ones are at, respectively, 15:00, 14:00 and 12:00 UTC. The VERA coordinates are given according to an origin point situated at $48.8^{\circ} \mathrm{N}$ and $7.0^{\circ} \mathrm{E}$ (see Fig. 1a). The color-coded areas on the simulation panels represent the vertical wind speed at the surface. The dashed line in the observations of the July 18 case shows a small wind divergence. 


\subsubsection{IOP 15a: August 12, 2007}

Figs. $4 \mathrm{c}$ and $\mathrm{d}$ represent the surface wind fields simulated and observed at 13:00 and 14:00 UTC respectively. The modelled horizontal wind field is characterized by a divergence line in the Rhine valley. This divergence line is also visible in the VERA analysis; however, it seems to be $10 \mathrm{~km}$ more to the west than in the simulation. Both observations and simulations show that the summit $\mathrm{S}$ of the northern Vosges massif is a convergence point between two flows coming from the Rhine valley and the west side of the mountains. This area seems to be more perturbed in the simulations than in the observations but this could also be attributed to the horizontal resolution, which is coarser in the observation $(8 \mathrm{~km})$ than in the simulations $(250 \mathrm{~m})$. The convergence seems to initiate some upward vertical motions that attain $+2.0 \mathrm{~m} \mathrm{~s}^{-1}$ which are favoured due to the instability of the atmosphere (Fig. 2b). This comparison shows that, in spite of a temporal bias and a somewhat lower intensity, the modelled surface wind field is close to the observed one.

\subsubsection{IOP 15b: August 13, 2007}

The Figs. $4 \mathrm{e}$ and $\mathrm{f}$ show, respectively, the modelled and the observed surface wind field at the precipitation formation moment and at 12:00 UTC. The westerly flow is more intense in this case than in the two others. The modelled horizontal wind seems to be channelled in the Rhine valley towards Burnhaupt. The intensity is quite high in the entire Rhine valley except near the Meistratzheim super-site (V point on the Fig. 1a) where the wind intensity is approximately zero and the direction is strongly perturbed. The surface horizontal wind field obtained with VERA (Fig. 4f) is quite similar to the simulated one. The decrease in the wind intensity visible near the east slopes of the Vosges Mountains is probably due to a convergence with the westerly flow. While the modelled intensity of the wind seems to be slightly lower in the simulation, the modelled wind field is globally close to the VERA analyses.

\subsection{GPS tomography}

The water vapour retrievals through GPS integrated water vapour 3D tomography are considered in this section and they are compared to the simulation results for each case. Indeed, when a dense network of GPS stations exists, as during the COPS campaign, GPS measurements can be used to retrieve the $3 \mathrm{D}$ distribution of water vapour density (FLORES et al., 2000; LABBOUZ et al., 2013). However, some difficulties can arise to retrieve the water vapour field in the boundary layer as it depends on the number of rays between GPS receivers and satellites available, as well as the receiver network density and configuration (BENDER and RAABE, 2007). During the COPS campaign the GPS network (50-55 GPS receivers) proved to be insufficiently dense and homogeneous in places while the cut-off angle was set fairly high such that only a limited number of rays would fill the lower atmosphere in parts of the analysis domain. Nevertheless, using appropriate horizontal and vertical resolution (about $10 \mathrm{~km}$ in latitude and longitude and $500 \mathrm{~m}$ height in this case) on an hourly basis, GPS tomography is still able to retrieve reasonable estimates of the water vapour distributions in the atmosphere above the area of interest where the network is adequately dense. But it must be kept in mind that at other areas, the number of rays in the grid box may not be sufficient and the effective resolution is actually coarser than the tomographic inversion grid (i.e. coarser than $10 \mathrm{~km}$ ). More details about the tomography procedures and limitations can be found in VAN BAELEN et al. (2011).

\subsubsection{IOP 9a: $18^{\text {th }}$ of July}

Figs. 5a and $\mathrm{b}$ show the water vapour fields respectively simulated with the Clark-Hall model and obtained with GPS tomography (VAN BAELEN et al., 2011). Traditionally, the water vapour is studied using the water vapour density field $\left(\mathrm{g} \mathrm{m}^{-3}\right)$ from GPS tomography whereas it is often characterised by the water vapour mixing ratio $\left(\mathrm{g} \mathrm{kg}^{-1}\right)$ from the model. In order to make the comparison between the simulation results and the observations easier, the modelled water vapour contents are given using the same unit as the GPS tomography field. In this way, to obtain the water vapour density, the water vapour mixing ratio field just need to be multiplied by the air density (in $\mathrm{kg} \mathrm{m}^{-3}$ ), which is function of the atmospheric temperature and pressure. Fig. 5a and b represent respectively the simulated and observed cross section centred at the Rhine valley near the exit of the Bruche valley at the latitude $48.6375^{\circ}$ (black segment in Fig. 4a). The simulated field shows the vapour water field 10 min before rain onset. SOLHEIM et al. (1999) show that the GPS sensitivities to liquid water are negligible. The observed field (Fig. 5b) is obtained at 17:00 UTC, i.e. 1-2 min after rain onset. It is noticeable in the observations that the water vapour content is more important $\left(13 \mathrm{~g} \mathrm{~m}^{-3}\right)$ in the Rhine valley and on the east slopes of the Vosges Mountains. The west slopes of the Vosges Mountains are less humid (9.5-10.5 $\left.\mathrm{g} \mathrm{m}^{-3}\right)$. Furthermore, the water vapour density is higher than $9.5 \mathrm{~g} \mathrm{~m}^{-3}$ in the first $1.5 \mathrm{~km}$ of the atmosphere. The simulated water vapour field is quite similar to the observations: the water vapour mixing ratio is more important in the Rhine valley, on the east slopes of the Vosges massif, and up to $1.5 \mathrm{~km}$ altitude. However, the water vapour mixing ratio seems to be larger at $\mathrm{x}=295 \mathrm{~km}$. The vicinity of the local sounding used in the set-up can explain this difference in the humidity field or the amount of water vapour that already condensed into cloud droplets which in turn formed rain 

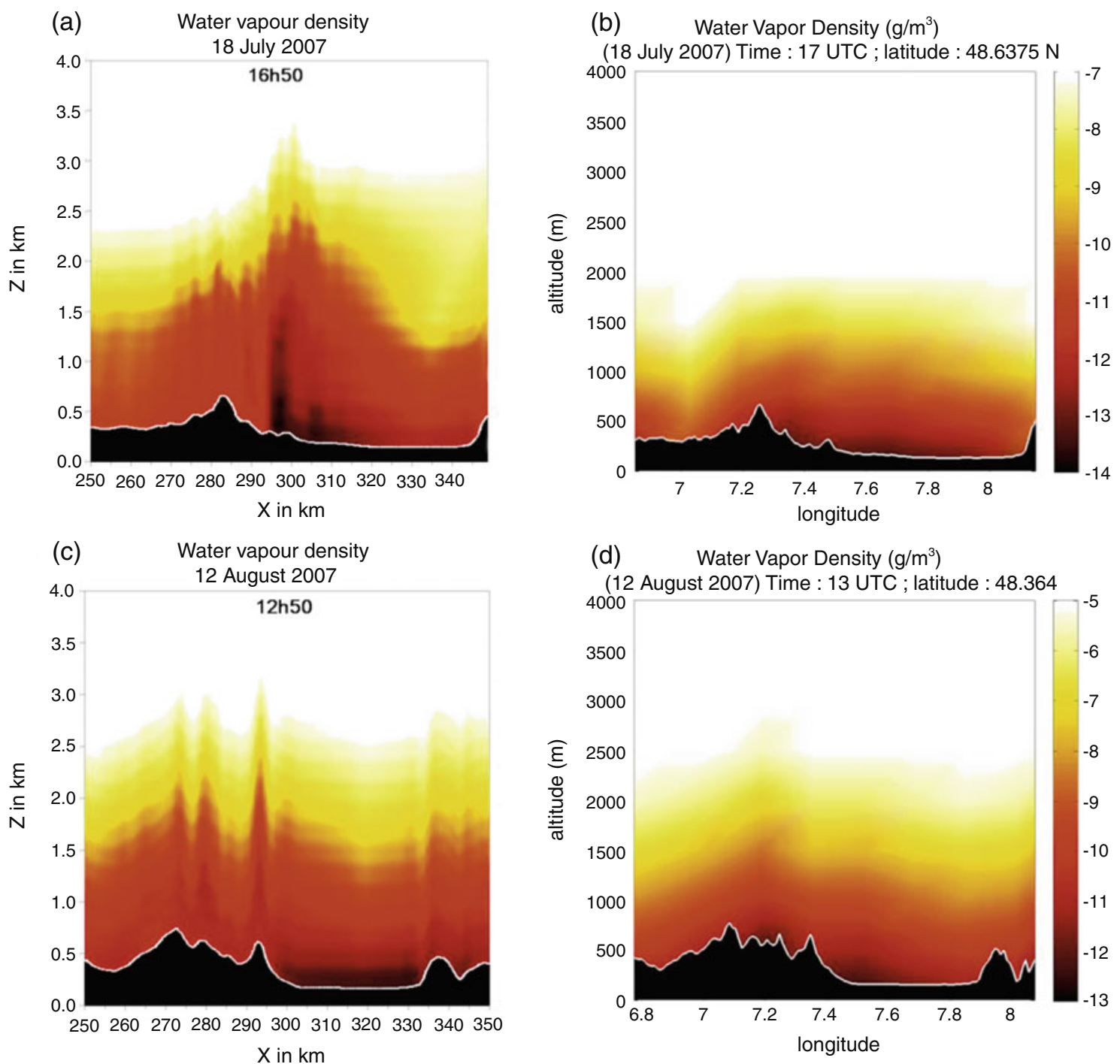

(d) Water Vapor Density $\left(\mathrm{g} / \mathrm{m}^{3}\right)$
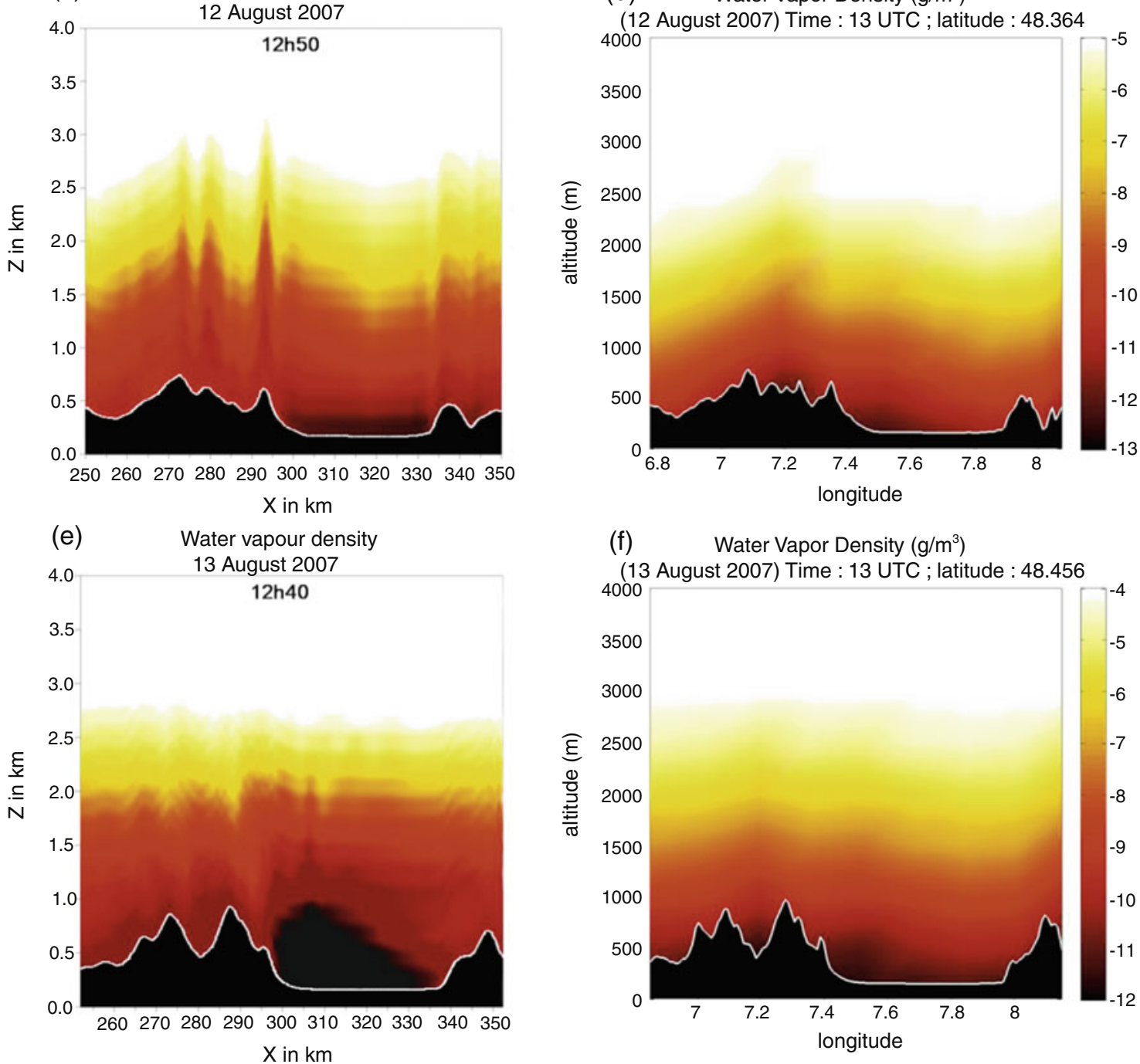

Figure 5: Comparison between the vertical water vapour density cross-sections modelled in the second domain 10 min before the rain onset (left panels) and obtained with the 3D GPS tomography (right panels, adapted from VAN BAELEN et al., 2011) at 17:00, 13:00 and 13:00 UTC, on July 18 (a-b) and August 12 (c-d) - 13 (e-f) case, respectively. The cross-section positions (illustrated in Figs. 4a, c and e) are chosen close to the convective system formation point. Note that the colour scales are different according to the studied case. 
drops is different between the GPS tomography and the simulation.

\subsubsection{IOP 15a: $12^{\text {th }}$ of August}

Figs. $5 \mathrm{c}$ and $\mathrm{d}$ show the same water vapour comparison for the August 12 case. The observation panel (Fig. 5d) shows the vertical cross section of the water vapour density at the latitude $48.364^{\circ}$ and at 13:00 UTC. So, this figure illustrates the atmospheric water vapour field at the onset of precipitation. The water vapour density is important in the western part of the Rhine valley (approx. $12.0 \mathrm{~g} \mathrm{~m}^{-3}$ in max). It seems that the water vapour field follows the topography because important quantities of water vapour (approx. $10.0 \mathrm{~g} \mathrm{~m}^{-3}$ ) are present up to $1.5 \mathrm{~km}$ high over the complex topography. Fig. $5 \mathrm{c}$ shows the simulated vertical cross section of the water vapour mixing ratio obtained $10 \mathrm{~min}$ before the rain onset and according to the same latitude in the observations. It is represented by the black segment on the Fig. 4c. Compared to the observations, the water vapour field seems to be slightly overestimated in the simulations which show important quantity of water vapour over the entire Rhine valley and not only in its west part. Indeed, the simulated water vapour density in the Rhine valley is approximately $12.5 \mathrm{~g} \mathrm{~m}^{-3}$ and $10.5 \mathrm{~g} \mathrm{~m}^{-3}$ in average over the relief. As for the observations, the simulated water vapour field seems to follow the relief of the Vosges Mountains. The strong westerly wind which crossed the massif could advect the water vapour along the relief. A gravity wave could have been formed; however, additional observations would have been necessary to confirm this hypothesis. Nevertheless, this phenomenon is more intense in the simulation results because important water vapour quantities (more than $10 \mathrm{~g} \mathrm{~m}^{-3}$ ) attain $2 \mathrm{~km}$ altitude.

\subsubsection{IOP 15b: $13^{\text {th }}$ of August}

Similarly, Figs. 5e and f represent a vertical cross section of the water vapour field, respectively, simulated and observed over the Rhine valley and the Vosges Mountains. The presented observations were obtained at the latitude $48.456^{\circ}$ and at 13:00 UTC, i.e. $10 \mathrm{~min}$ after the formation of the second precipitating cell. The simulated cross section which is obtained along the same latitude (black segment on the Fig. 4e) represents the water vapour field 10 min before the rain onset of the second precipitating cell. The observation panel shows that the water vapour is more important in the west part of the Rhine valley where it attains up to $12 \mathrm{~g} \mathrm{~m}^{-3}$. The simulated water vapour density trends are comparable with an important amount close to the east slopes of the Vosges. This bias can be explained by the time of the observations when some condensation into cloud droplets already occurred and precipitation formed. Moreover, the atmosphere is more humid in the simulation than in the GPS tomography at $2 \mathrm{~km}$ height. As this bias is less than $500 \mathrm{~m}$ (GPS tomography resolution), additional observations would be necessary to quantify the boundary layer height. Nevertheless, this type of observations (e.g. lidar measurement) was not available in August at the V supersite.

\section{Local characteristics of the convective system formation}

The above comparative studies between the simulation results and the observations of the precipitating, water vapour and surface horizontal wind fields show a reasonable agreement. The radar reflectivities and the water vapour contents are well comparable with the observations. However, a slight temporal offset in the horizontal wind field was highlighted above. Nevertheless, as in general the features of the observed convective systems were well reproduced by the model, the investigations are refined to understand the impact of the terrain on the formation of these three convective systems.

\subsection{IOP 8a: $18^{\text {th }}$ of July}

As described in Section 3, the horizontal wind field is marked by a convergence near the exit of the Bruche valley in the lee side of the Vosges where the amounts of water vapour are important. Around this convergence, the wind velocity decreases to about $1.5 \mathrm{~m} \mathrm{~s}^{-1}$. Fig. $4 \mathrm{a}$ also shows that the vertical motions, which vary over a small range of +0.5 and $-1.0 \mathrm{~m} \mathrm{~s}^{-1}$, are not organised. The development of the updrafts is probably due to the atmospheric instability (see Section 2) and/or the complex mountainous area. As a consequence, the association of the wind convergence, the available humidity, the atmospheric instability in the lowest altitudes and the topography of the Vosges Mountains probably caused the triggering of the convective precipitating system. The following study aims to find out what is the most prominent influence.

In order to evaluate the influence of the topography in the formation of the convective system observed on $18^{\text {th }}$ of July 2007, the air masses responsible to the initiation of the precipitating system will be studied. According to the horizontal wind field at the surface (Fig. 4a) and a back-trajectories analysis (not illustrated), the airflows are channelled in the Bruche valley and hit some hills present at the exit of the valley (see Fig. 1b). These hills may have forced the lifting of the air and thus help to trigger the convection. Consequently, to understand the role of these hills in the formation of the convective system observed on July 18, a study suppressing the topography at the exit of the Bruche valley (see square on the Figs. 1b) was performed. Indeed, these small hills were deleted to obtain a flat terrain considering the surrounding topography. However, this main modification in the topography did not affect the formation of the 
precipitating system and this study reveals that the hills at the exit of the Bruche valley did not influence the triggering of the convection; however, the overall Vosges massif seems to play a main role as it strongly modifies the horizontal wind field at the surface creating an important convergence in the eastern foothills of the Vosges and channels the airflow in the Bruche valley.

\subsection{IOP 15a: $12^{\text {th }}$ of August}

Fig.4c represents the simulated surface horizontal wind in the innermost domain for August 12 and during the formation of the convective system. As suggested by the wind profile of Fig. $2 b$ the strength of horizontal wind remains globally quite low with values less than $2-3 \mathrm{~m} \mathrm{~s}^{-1}$, except above the Vosges ridges with a maximum of about $6.5 \mathrm{~m}$ $\mathrm{s}^{-1}$. All the flow seem to converge toward the summit $\mathrm{S}$ of the northern Vosges. Fig. 4c shows that the vertical wind velocity ranges from $-2 \mathrm{~m} \mathrm{~s}^{-1}$ to $+3.0 \mathrm{~m} \mathrm{~s}^{-1}$. Weak vertical motions prevail in the surface layer all over the mountainous area. Probably due to the convergence and the atmospheric instability (see sounding on Fig. 2b), some significant updrafts are formed over the summit $\mathrm{S}$ (Fig. 4c) close to the convective system formation (Fig. 1b). This convective development is confirmed by the analysis of the pressure perturbation, which reaches $0.7 \mathrm{hPa}$ close to the summit S (not illustrated). Fig. 6 shows several 20 min back trajectories (in the area of $10 \times 10 \mathrm{~km}^{2}$ represented by the small dashed square around the summit $\mathrm{S}$ in Fig. 4c) to study the characteristics of air parcels travelling towards the summit $\mathrm{S}$. These back-trajectories are calculated by means of the simulated four-dimensional wind field $\left(250 \times 250 \times 200 \mathrm{~m}^{3}\right)$, which is available in time steps of $3 \mathrm{~s}$. The origin points were chosen in the cloud levels, i.e. between 1000 and $1600 \mathrm{~m}$ agl, where super-saturation occurs. Fig. 6 reveals that the convective system is fed by flow coming both from the west slopes of the Vosges

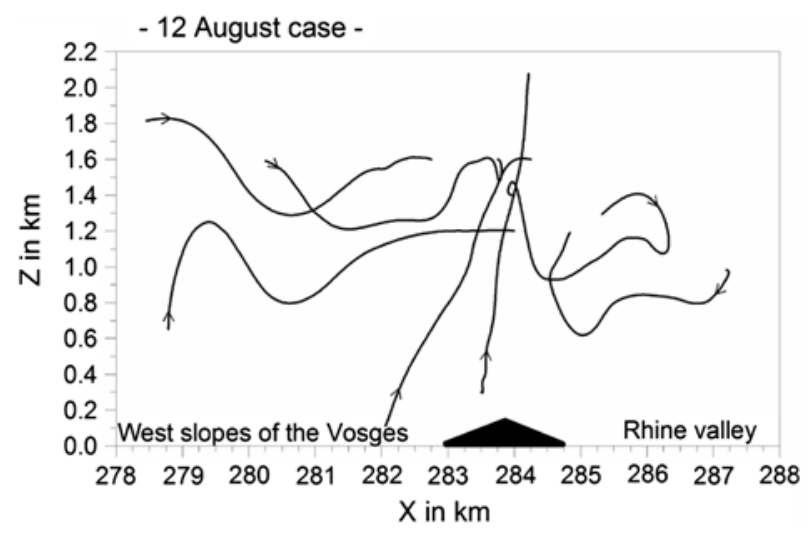

Figure 6: Vertical cross section of the 20 min back-trajectories converging close to the convective system formation point on August 12 . The area of this study is represented by the dashed black line on the Fig. 4c. The height corresponds to the altitude above the ground level and the black triangle represents the summit of the northern Vosges massif. and the Rhine valley confirming the convergence depicted in Fig. 4c. The association of the Figs. $4 \mathrm{c}$ and $5 \mathrm{c}$ shows that the air flow forming the convergence comes from humid areas. To summarize, the formation of the convective cells on August 12 is probably mainly due to the topography of the Vosges Mountains and particularly the summit $\mathrm{S}$ which forced the updrafts of the humid air flow. The strong instability in the lowest levels $(1500 \mathrm{~m})$ of the atmosphere is then favourable to vertical developments under these forced conditions.

\subsection{IOP 15b: $13^{\text {th }}$ of August}

Fig. 4e shows that the surface wind velocities are higher over the Vosges than in the Rhine valley. There is a westerly flow over the relief, which becomes northerly in the north of the Vosges, whereas it is north-easterly in the Rhine valley. The different flows create a convergence $10 \mathrm{~km}$ south of the X-band radar position (Fig. 4e). This convergence area $(140<\mathrm{y}<175 \mathrm{~km})$ is marked by a very low wind velocity and by the development of weak updrafts equal to $0.15 \mathrm{~m} \mathrm{~s}^{-1}$ over a large area. This strong perturbation in the surface horizontal wind field seems to be due to the steep eastern slopes of the Vosges. Indeed, the strong westerly flow probably travelled deeper into the valley and thus blocked the north-easterly flow. Moreover, this intense flow seems to initiate vertical motions around the hill where the X-band radar was deployed. In order to understand the influence of the local environment, a focussed analysis to a smaller area $(10 \mathrm{x}$ $10 \mathrm{~km}^{2}$ ) surrounding the convective cloud triggering is performed. This area is represented by the dashed line in Fig. 4e. Figs. 7a and b represent the horizontal and vertical cross sections of the 20 min back-trajectories of the airflow that initiated the convective system. The crosses on each panel represent the origin point of the back-trajectory. The departure points are chosen at $1.2 \mathrm{~km}$ altitude where the environment is super-saturated. Fig. 7a shows that two groups of trajectories (in black and grey) can be detected in the horizontal cross section. The first group of back-trajectories (in black) represents a dominant eastward airflow. The travelled distance is about 6$7 \mathrm{~km}$. The second group of back-trajectories (in grey) illustrates a less intense south-eastward flow because in the same lapse time the air mass only travelled across $1-2 \mathrm{~km}$. The vertical cross section of the trajectories depicted in Fig. $7 \mathrm{~b}$ shows that their origins are different and easily explains their two trends. Air parcels with shorter trajectories are coming from lower atmospheric levels whereas the longer ones crossed the Vosges relief at an altitude of $1.2 \mathrm{~km}$. In fact, the smaller flow is probably induced by local conditions whereas the more intense flow seems to be produced by the synoptic conditions. Fig. 8 represents a vertical cross section of the horizontal windspeed in the innermost domain for August 13 according to the black segment in Fig. 4e and at the beginning of the system formation. The Vosges Mountains appear like a natural barrier. It seems that the 

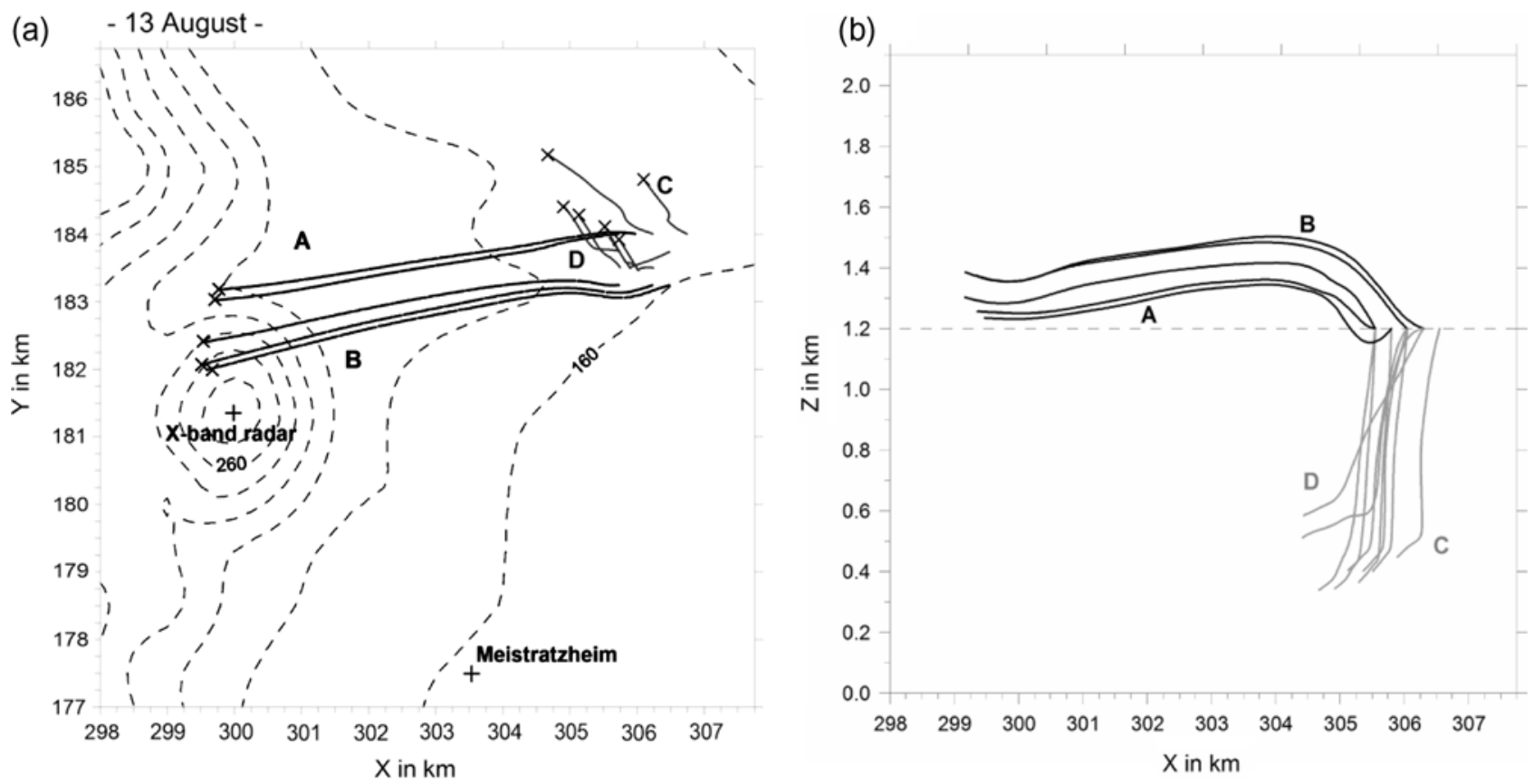

Figure 7: Horizontal (a) and vertical (b) cross section of the 20 min back-trajectories that track the air parcels that trigger the convective system observed on August 13. The area of this study is represented by the dashed black line on the Fig. 4e. The letters are used to easier understand the position of the different back-trajectories and the crosses represent the origin points of the back-trajectories.

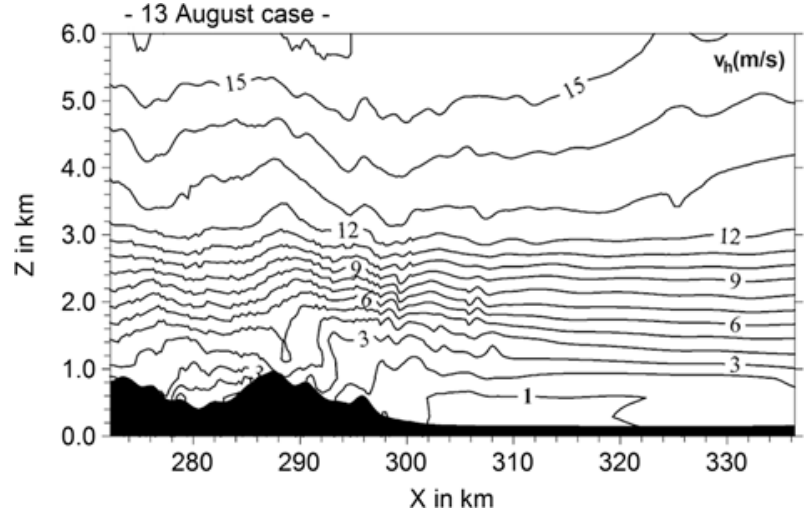

Figure 8: Simulated horizontal wind speed in the innermost model domain on August 13, at 13:30 UTC. The location of the cross section is illustrated in Fig. 4e.

lowest levels of the atmosphere above the Rhine valley are isolated. Indeed, the horizontal wind speeds remain below 1 and $2 \mathrm{~ms}^{-1}$ in the first km above the Rhine valley, while the wind speed increases from 3 to $12 \mathrm{~m} \mathrm{~s}^{-1}$ from 1.2 to $3 \mathrm{~km}$ height. Figs. 8 and $7 \mathrm{~b}$ show that a strong vertical shear prevails around $1.2 \mathrm{~km}$ height. It seems that, under the calm conditions of the lowest altitudes, the convection was able to form due to the local thermodynamics and stability conditions (see Fig. 2c). Once cloud formation has started (about $800 \mathrm{~m} \mathrm{agl}$ ), a moderate wind shear is visible at $1.2 \mathrm{~km}$ (altitudes corresponding to the top of the Vosges). HouZE (1993) showed that the wind shears affect convective development in two ways. First, the large-scale wind shears may have impacts on the structures of forming convective systems. Second, they change the dynamic instability conditions because of the resulting modification of the vertical structure. However, according to the local conditions of instability, CAPE and humidity, the wind shear could have an opposite impact on the convective system development. Specifically, the wind shear could tend to promote storm organisation and longevity, although an excessive wind shear in instable environments can be detrimental to convection initiation by increasing entrainment. It seems, in this case, that the local conditions induced by wind shear provide a significant enhancement of the convection processes. As a consequence, this intense convective system was able to cross the Rhine valley as shown by the POLDIRAD radar observations (HAGEN et al., 2011).

\section{Discussion and conclusions}

In this study the 3D Clark-Hall cloud scale model (CLARK et al., 1996) with high horizontal and vertical resolution is used to simulate different convective summertime systems with small horizontal extension, and to analyse the influence of the orography on their formation mechanisms. The studied cloud systems are observed on July 18 and August 12-13, 2007 over the Vosges Mountains during the COPS campaign that took place at the French/German border during the summer 2007. The three studied cases characterise both convection initiation locations established in the Hagen et al. classification (HAGEN et al., 2011). To simulate the 
different cases, a nesting procedure to focus on the Vosges area is used in order to represent the synoptic influences and reproduce the small scale orography features with a good accuracy. Moreover, the radiative effects on the slopes are considered in the model but their influences on the development of the convection were not analysed in this paper. The simulation results are then compared with the available observation data provided by the high resolution X-band radar (VAN BAELEN et al., 2009) that was deployed on the V supersite (Vosges), the VERA analysis of the wind field at the surface (BAUER et al., 2011) and the water vapour retrieval through GPS integrated water vapour 3D tomography (VAN BAELEN et al., 2011). The comparative studies were only possible when the closest ECMWF profile was replaced by the observed local sounding. Indeed, the generic ECMWF profiles underestimated the humidity in the lowest levels of the atmosphere, an essential feature for the development of the three convective systems. The comparative studies reveal that the model reasonably reproduces the radar reflectivities of the X-band radar, the water vapour tomography field and the VERA analysis of the surface horizontal wind. There were just some slight biases in the temporal evolution of the horizontal wind. This can be attributed either to the spatial $(8 \mathrm{~km})$ and temporal $(1 \mathrm{~h})$ resolutions that are coarser in the VERA analysis, or to the poor surface representation in the model. In the future, a detailed surface scheme should be coupled to the Clark-Hall cloud scale model to better take into account the influence of the surface layer for the convective system development. These first conclusions demonstrate the capability of the model to reproduce the observed fields and the resulting requirement to have a dense observation network to correctly initiate the model over mountainous area and also, to well represent the orography influence on the precipitation contents.

According to our study of these three convective cloud systems it is impossible to establish an identical influence of the relief on their triggering. Indeed, the orography influence is different depending to the local conditions. Nevertheless, these local conditions reveal some common points irrespective of the studied case. For example, an instability is present in the lowest levels of the atmosphere for each case, and the water vapour fields reveal that the humidity close to the origin of system formation (in the western part of the Rhine valley) is important, i.e. approximately $12-12.5 \mathrm{~g} \mathrm{~m}^{-3}$. Furthermore, the maxima of the precipitation intensity are quite similar $(\approx 50 \mathrm{dBZ})$. However, the main differences in the formation of the convective cases are the wind properties: intensity and direction. For example, the August 12 case is characterised by a more intense vertical wind speed than the two others. Moreover, the synoptic conditions of the August 13 case seem to provoke a more intense westerly flow. It seems nevertheless that the orography has more influence on the wind than on the other meteorological studied fields. Indeed, on $18^{\text {th }}$ of July the terrain produces a convergence in the lee side of the Vosges
Mountains as well as a channelling of the horizontal wind in the Bruche valley. On August 12, the instability and the relief favour the development of some vertical motions. They induce then a local pressure perturbation which results in the convergence of the surrounding airflows and the enhancement of more intense uplifts that are directly associated with the summit S. BANTA (1990) described this organisation as a thermal convergence. Otherwise, on August 13, the massif permits the development of a convergence in the Rhine valley close to the eastern foothills of the Vosges. In association to this convergence, the mountains isolate the lowest levels of the atmosphere from the high wind velocities enabling the triggering of the convection by means of the local instability and thermodynamics conditions. The Vosges massif behaves like a natural barrier for the high intensity synoptic eastward flow and provokes a moderate shear which then intensifies the convective system.

In this paper, the important role that mountains with moderate topography play in the formation of the precipitating systems, by providing the necessary lifting mechanism, has been evidenced. These updrafts can be influenced by the terrain in a straightforward manner, such as a forced orographic ascent (i.e. in the August 12 case). The mountainous area can also initiate uplifts by more indirect manners, such as airflow deflection or convergence in the lee side of the massif, waves provided by flow over the reliefs, and finally, this natural barrier can also block the air flow (i.e. in the July 18 and August 13 cases). However, the convective systems are not formed by the mountains themselves, but require, in combination, some moisture, proper stability, and some supportive synoptic or mesoscale environment forcing.

\section{Acknowledgments}

The lead author would like to thank the anonymous reviewers for their precise and constructive comments which have significantly contributed to the improvement of the article.

The COPS campaign implementation and the instrument participation (radars in this instance) were made possible through the financial support of the ANR (grant ANR-06-BLAN-0018-04: COPS/France) and CNRS/ INSU (LEFE/IDAO program) in France. The calculations for this study have been done on computer facilities of IDRIS, CNRS at Orsay and CINES in Montpellier, under the project 940180 . The authors acknowledge with gratitude the hours of computer time and the support provided.

\section{References}

BANTA, R., 1990: The role of mountain flows in making clouds. - Meteor. Monogr. 23, 229-283.

Barros, A. P., D. P. Lettenmaier, 1994: Dynamic modelling of orographically induced precipitation. $-\underline{\text { Rev. }}$ Geophys. 32, 265-284. 
Bauer, H. S., T. WeusthofF, M. DORninger, V. Wulfmeyer, T. SchWitAlla, T. Gorgas, M. Arpagaus, K. WARRACH-SAGI, 2011: Predictive skill of a subset of models participating in D-PHASE in the COPS region. Quart. J. Roy. Meteor. Soc. 137, 287-305.

BENDER, M., A. RAABE, 2007: Preconditions to ground based GPS water vapour tomography. - Ann. Geophys. 25, 1727-1734.

BERRY, E. X., R. L. REINHARDT, 1974a: An analysis of cloud drop growth by collection: Part I: Double distributions. - J. Atmos. Sci. 31, 1814-1824.

BERRY, E. X., R. L. REINHARDT, 1974b: An analysis of cloud drop growth by collection: Part II: Single initial distributions. - J. Atmos. Sci. 31, 1825-1831.

Bougeault, P., P. Binder, A. Buzzi, R. Dirks, R. Houze, J. Kuettner, R. B. SMith, R. Steinacker, H. Volkert, 2001: The MAP special observing period. - Bull. Amer. Meteor. Soc. 82, 433-462.

Browning, K., A. Blyth, P. Clark, U. Corsmeier, C. Morcrette, J. Agnew, D. BAmber, C. BArthlott, L. BenNett, K. BesWiCK, M. BitTer, K. BOZIER, B. BroOKS, C. Collier, C. CoOK, F. Davies, B. Deny, T. Feuerle, R. Forbes, C. GAFFARD, M. CRAY, R. HANKERS, T. HEWISON, N. KalthofF, S. KHODAYAR, M. KoHLER, C. KotTMEIER, S. KRAUT, M. KUnZ, D. LADD, J. LENFANT, J. MARSHAM, J. McGregor, J. Nicol, E. Norton, D. PArker, F. PERry, M. RAMATSCHI, H. RICKETTS, N. ROBERTS, A. RUSSELL, H. Schulz, E. Slack, G. Vaughan, J. Waight, R. WATsON, A. WeBB, A. WIESER, 2007: The convective storm initiation project. - Bull. Amer. Meteor. Soc. 88, 1939-1955.

Bruintjes, R. T., T. L. Clark, W. D. Hall, 1994: Interaction between topographic airflow and cloud/precipitation development during the passage of a winter storm in Arizona. - J. Atmos. Sci. 51, 48-67.

CLARK, T. L., 1977: A small scale dynamic model using terrain following coordinate transformation. - J. Comput. Phys. 24, 186-215.

CLARK, T. L., 1979: Numerical simulations with a three dimensional cloud model: lateral boundary condition experiments and multi-cellular severe storm simulations. - J. Atmos. Sci. 36, 2191-2215.

CLARK, T. L., W. D. HALL, 1991: Multi-domain simulations of the time dependent Navier-Stokes equations: benchmark error analysis of some nesting procedures. - J. Comput. Phys. 92, 456-481.

Clark, T.L., W.D. Hall, J.L. CoEN, 1996: Source code documentation for the Clark-Hall cloud scale model, code version G3CH01. NCAR/TN-426+STR. - NCAR Technical note, NCAR, Boulder, CO, USA.

ClARK, T. L., W. D. HALl, R. M. KeRR, D. MidDleton, L. RADKE, F. RALPH, P. NEIMAN, 2000: On the origins of aircraft damaging clear-air turbulence during the 9 December 1992 Colorado downslope windstorm: Numerical simulations and comparison with observations. - J. Atmos. Sci. 57, 1105-1131.
COSMA, S., E. RichARD, F. MinisclOUX, 2002: The role of small-scale orographic features in the spatial distribution of precipitation. - Quart. J. Roy. Meteor. Soc. 128, 75-92.

DANKO, D. M., 1992: The digital chart of the world. GeoInfo Systems 2, 29-36.

DeE, D. P., S. M. UpPala, A. J. Simmons, P. Berrisford, P. Poli, S. Kobayashi, U. Andrae, M. A. Balmaseda, G. BAlsamo, P. BAuer, P. Bechtold, A. C. M. BelJAARs, L. van de BERG, J. BIDlOt, N. BORMANN, C. Delsol, R. Dragani, M. Fuentes, A. J. Geer, L. Haimberger, S. B. Healy, H. Hersbach, E. V. Hólm, L. IsAKSEN, P. KÅLlBERG, M. KÖHLER, M. MATRICARDI, A. P. MCNally, B. M. Monge-Sanz, J.-J. Morcrette, B.-K. Park, C. Peubey, P. de Rosnay, C. Tavolato, J.-N. THÉPAUT, F. VITART, 2011: The ERA-Interim reanalysis: configuration and performance of the data assimilation system. - Quart. J. Roy. Meteor. Soc. 137, 553-597. DOI: 10.1002/qj.828.

DORNINGER, M., S. SCHNEIDER, R. STEINACKER, 2008: On the interpolation of precipitation data over complex terrain. - Meteor. Atmos. Phys. 101, 175-189.

EigENMANN, R., S. METZGER, T. FoKEN, 2009: Generation of free convection due to changes of the local circulation system. - Atmos. Chem. Phys. 9, 8587-8600.

Flores, A., A. RiUs, G. RUFFINI, 2000: 4D tropospheric tomography using GPS slant wet delays. - Ann. Geophys. 18, 223-224.

HÄBerli, C., I. Groehn, R. Steinacker, W. PöttschACHER, M. DORNINGER, 2004: Performance of the surface observational network during MAP. - Meteorol. Z. 13, 109-121.

HAGEN, M., J. Van BAELEN, E. RICHARD, 2011: Influence of the wind profile on the initiation of convection in mountainous terrain. - Quart. J. Roy. Meteor. Soc. 137, 224-235.

Houze, R., 1993: Cloud dynamics - Academic Press, New York, $573 \mathrm{pp}$.

KoEnIG, L. R., F. W. Murray, 1976: Ice-bearing cumulus cloud evolution: numerical simulation and general comparison against observations. - J. Appl. Meteor. 15, 747762.

KONDRATYEV, K., 1969: Radiation in the atmosphere. AcademicPress; New-York, 912 pp.

Kottmeier, C., N. Kalthoff, C. Barthlott, U. CorsMeier, J. VAn BAelen, A. Behrendt, R. Behrendt, A. Blyth, R. Coulter, S. Crewell, P. Di Girolamo, M. Dorninger, C. Flamant, T. FOKEN, C. HAUCK, H. HÖLlER, M. KUNZ, H. MAHLKE, S. MOBBS, E. RiCHARD, R. STEINACKER, T. WECKWERTH, A. WIESER, W. WULFMEYER, 2008: Mechanisms initiating deep convection over complex terrain during COPS. - Meteorol. Z. 17, 931-948. LABbouZ, L., J. Van BAElen, F. TRIDON, M. REVERDY, M. HAgen, M. Bender, G. DiCK, T. Gorgas, 2013: Precipitation on the lee side of the Vosges mountains: Multi-instrumental study of one case from the COPS campaign. - Meteorol. Z. 22, $\mathrm{xxx}-\mathrm{xxx}$, this issue 
Leroy, D., W. Wobrock, A. I. Flossmann, 2009: The role of boundary layer aerosol particles for the development of deep convective clouds: a high-resolution 3D model with detailed (bin) microphysics applied to CRYSTAL-FACE. Atmos. Res. 91, 62-78.

MAHRER, Y., R. A. PIELKE, 1977: A numerical study of the air flow over irregular terrain. - Contrib. Atmos. Phys. 50, 98-113.

ORLANSKI, I., 1976: A simple boundary condition for unbounded hyperbolic flows. - J. Comput. Phys. 21, 251-269.

PASTOR, F., I. GOMEZ, M. J. EstrelA, 2010: Numerical study of the October 2007 flash flood in the Valencia region (Eastern Spain): the role of orography. - Natural Hazards Earth Sys. Sci. 10, 1331-1345.

Peters, G., B. Fischer, M. Clemens, 2006: Areal homogeneity of Z-R relations. - European conference on radar in meteorology and hydrology (ERAD), Barcelona, Spain.

Planche, C., W. Wobrock, A. I. FlossmanN, F. Tridon, J. VAn BAElen, Y. Pointin, M. HAGEN, 2010: The influence of aerosol particle number and hygroscopicity on the evolution of convective cloud systems and their precipitation: A numerical study based on the COPS observations on 12 August 2007. - Atmos. Res. 98, 40-56.

SCHROTH, A. C., M. S. CHANDRA, P. MEISCHNER, 1988: A C-band polarimetric radar for propagation and cloud physics research. - J. Atmos. Ocean. Technol. 5, 803-822.

Simmons, A., S. UpPalA, D. DEE, S. KobAYASHI, 2007: ERAInterim: New ECMWF reanalysis products from 1989 onwards. - Newsletter 110, Winter 2006/07, ECMWF, 11 pp.

SMAGORINSKY, J., 1963: General circulation experiments with the primitive equations. I. The basic experiment. Mon. Wea. Rev. 91, 99-164.

SMITH, R. B., 1979: The influence of mountains on the atmosphere. - Advan. Geophys. 21, 87-223.

SOlHeim, F. S., J. VIVEKANANDAN, R. H. WARE, C. ROCKEN, 1999: Propagation delays induced in GPS signals by dry air, water vapor, hydrometeors, and other particulates. - J. Geophys. Res. 104, 9663-9670.

SteINACKER, R., C. HÄBERLI, W. PÖTTSCHACHER, 2000: A transparent method for the analysis and quality evaluation of irregularly distributed and noisy observational data. Mon. Wea. Rev. 128, 2303-2316.

STEINACKER, R., M. RATHEISER, B. BICA, B. ChIMANI, M. DORNINGER, W. GEPP, C. LOTTERANER, S. SCHNEIDER, S. TSCHANNETT, 2006: A mesoscale data analysis and downscaling method over complex terrain. - Mon. Wea. Rev. 134, 2758-2771.

StraKA, J. M., D. S. ZRNiĆ, A. V. RYZHKOV, 2000: Bulk hydrometeor classification and quantification using polarimetric radar data: synthesis of relations. - J. Appl. Meteor. 39, 1341-1372.

STULL, R.B., 1988: An introduction to boundary layer meteorology. - Kluwer Academic Publishers, Boston, $666 \mathrm{pp}$.
UiJlenhoet, R., S. H. VAN DER Wielen, A. BERne, 2006: Uncertainties in rainfall retrievals using weather radar. Hydrol. Earth Sys. Sci. Discuss. 3, 2385-2436.

Van Baelen, J., Y. Pointin, W. Wobrock, A. FlossMANN, G. Peters, F. Tridon, C. Planche, 2009: Precipitation and microphysical studies with low cost high resolution X-band radar: an innovative project prospective. - Adv. Geosci. 20, 25-32.

VAn BAelen, J., M. Reverdy, F. Tridon, L. LabBouZ, G. DiCK, M. BENDER, M. HAGEN, 2011: On the relationship between water vapour field evolution and the life cycle of precipitation systems. - Quart. J. Roy. Meteor. Soc. 137, 204-223.

Weckwerth, T. M., D. B. Parsons, S. E. Koch, J. A. Moore, M. A. LeMone, B. Demoz, C. Flamant, B. GeERTS, J. WANG, W. F. FELTZ, 2004: An overview of the international $\mathrm{H} 2 \mathrm{O}$ project (IHOP-2002) and some preliminary highlights. - Bull. Amer. Meteor. Soc. 85, 253 277.

Wobrock, W., A. I. Flossmann, R. D. Farley, 2003: Comparison of observed and modeled hailstone spectra during a severe storm over the Northern Pyrenean foothills. - Atmos. Res. 67-68, 685-703.

Wulfmeyer, V., A. Behrendt, H. S. BAuer, C. KottmeIER, U. CORSMEIER, A. BLYTH, G. CRAIG, U. SCHUMANN, M. Hagen, S. Crewell, P. Di Girolamo, C. Flamant, M. Miller, A. Montani, S. Mobbs, E. Richard, M. W. Rotach, M. Arpagaus, H. RusSCHENBERG, P. SCHLÜSSEL, M. KÖNIG, V. GÄRTNER, R. STEINACKER, M. Dorninger, D. D. Turner, T. WeCKWERTh, A. Hense, C. SIMMER, 2008: The Convective and Orographicallyinduced Precipitation Study: a research and development project of the world weather research program for improving quantitative precipitation forecasting in lowmountain regions. - Bull. Amer. Meteor. Soc. 89, $1477-$ 1486.

Wulfmeyer, V., A. Behrendt, C. Kottmeier, U. CorsMeier, C. Barthlott, G. C. Craig, M. Hagen, D. Althausen, F. Aoshima, M. Arpagaus, H. S. Bauer, L. Bennett, A. Blyth, C. Brandau, C. Champollion, S. CREWEll, G. Dick, P. Di Girolamo, M. DORninger, Y. Dufournet, R. Eigenmann, R. Engelmann, C. Flamant, T. FoKen, T. GORGAS, M. GRZESCHIK, J. HANDWERKER, C. HAUCK, H. HÖLLER, W. JUNKERMANN, N. Kalthoff, C. Kiemle, S. KlinK, M. KÖNig, L. Krauss, C. N. Long, F. Madonna, S. MobBs, B. Neininger, S. Pal, G. Peters, G. Pigeon, E. Richard, M. W. Rotach, H. RusschenberG, T. SchWitalla, V. SMith, R. STEINACKER, J. TRENTMANN, D. D. TURNER, J. van BAELEN, S. VOGT, H. VOLKERT, T. WECKWERTH, H. WERnLI, A. WIESER, M. WIRTH, 2011: The Convective and Orographically induced Precipitation Study (COPS): The scientific strategy, the field phase, and research highlights. - Quart. J. Roy. Meteor. Soc. 137, 3-30. 